\title{
Endogenous Il10 Alleviates the Systemic Antiviral Cellular Immune Response and T Cell-Mediated Immunopathology in Select Organs of Acutely LCMV-Infected Mice
}

Kristin Jakobshagen, ${ }^{*}$ Beate Ward, ${ }^{*}$ Nikola Baschuk, ${ }^{*}$ Sebastian Huss, ${ }^{\dagger}$ Anna Brunn, ${ }^{\ddagger}$ Monika Malecki, ${ }^{*}$ Michael Fiolka, ${ }^{*}$ Gunther Rappl, ${ }^{\delta}$ Diana Corogeanu, ${ }^{*}$ Ulrike Karow, ${ }^{*}$ Petra Schiller, ${ }^{\|}$Hinrich Abken, ${ }^{, \uparrow}$ Lukas C. Heukamp, ${ }^{\dagger}$ Martina Deckert, Martin Krönke, ${ }^{*} * *$ and Olaf Utermöhlen*ף

From the Institute for Medical Microbiology, Immunology and Hygiene * and the Center for Molecular Medicine Cologne, "University of Cologne, Cologne; the Institutes of Pathology ${ }^{\dagger}$ and Medical Statistics, Informatics and Epidemiology," and the Departments of Neuropathology ${ }^{\ddagger}$ and Internal Medicine I, University Hospital Cologne, Cologne; and the German Center for Infection Research (DZIF), partner site Bonn-Cologne, ** Cologne, Germany

\author{
Accepted for publication \\ July 14,2015 \\ Address correspondence to \\ Olaf Utermöhlen, M.D., Insti- \\ tute for Medical Microbiology, \\ Immunology and Hygiene, \\ University of Cologne, Golden- \\ felsstraße 19-21, D-50935 Co- \\ logne, Germany. E-mail: olaf. \\ utermoehlen@uk-koeln.de.
}

\begin{abstract}
The immunoregulatory cytokine IL-10 suppresses T-cell immunity. The complementary question, whether IL-10 is also involved in limiting the collateral damage of vigorous T cell responses, has not been addressed in detail. Here, we report that the particularly strong virus-specific immune response during acute primary infection with the lymphocytic choriomeningitis virus (LCMV) in mice is significantly further increased in I10-deficient mice, particularly regarding frequencies and cytotoxic activity of $\mathrm{CD}^{+} \mathrm{T}$ cells. This increase results in exacerbating immunopathology in select organs, ranging from transient local swelling to an increased risk for mortality. Remarkably, LCMV-induced, T cell-mediated hepatitis is not affected by endogenous Il10. The alleviating effect of Il10 on LCMV-induced immunopathology was found to be operative in delayed-type hypersensitivity footpad-swelling reaction and in debilitating meningitis in mice of both the $\mathrm{C} 57 \mathrm{BL} / 6$ and $\mathrm{BALB} / \mathrm{c}$ strains. These strains are prototypic counterpoles for genetically imprinted type 1-biased versus type 2-biased T cell-mediated immune responses against various infectious pathogens. However, during acute LCMV infection, neither systemic cytokine patterns nor the impact of Il10 on LCMV-induced immunopathology differed conspicuously between these two strains of mice. This study documents a physiological role of Il10 in the regulation of a balanced T-cell response limiting immunopathological damage. (Am J Pathol 2015, 185: 3025-3038; http://dx.doi.org/10.1016/j.ajpath.2015.07.019)
\end{abstract}

The cytokine IL-10 is an immunoregulatory master switch that inhibits innate as well as adaptive immune responses (reviewed by Moore et $\mathrm{al}^{1}$ and $\mathrm{O}^{\prime} \mathrm{Garra}$ et $\mathrm{al}^{2}$ ). $\mathrm{Il10}$ has been reported to limit virus-specific immune responses during acute infection, such as with influenza virus, ${ }^{3,4}$ herpes simplex virus, ${ }^{5}$ and murine cytomegalovirus. ${ }^{6}$ Similarly, Il10 contributes to inhibiting virus-specific immunity during persistent viral infections, such as with murine cytomegalovirus ${ }^{7,8}$ or lymphocytic choriomeningitis virus (LCMV). ${ }^{9,10}$ In particular, in mice persistently infected with LCMV, abolishing Il10 activity leads to restoring an effective immune response that eliminates the virus. 9,10 Consequently, therapeutic strategies to block the
Supported by the Center for Molecular Medicine Cologne projects B6 and TP04 (M.K. and O.U.) from the Deutsche Forschungsgemeinschaft, Collaborative Research Center 670.

K.J. and B.W. contributed equally to this work.

Disclosures: None declared.

Current address of N.B., Department of Biochemistry and Genetics, La Trobe Institute for Molecular Science, La Trobe University, Melbourne, Victoria, Australia; of S.H., Gerhard-Domagk Institute for Pathology, University Clinics Münster, Münster, Germany; of M.M., Institut für Hygiene, Kliniken der Stadt Köln, Cologne, Germany; of D.C., University of Medicine and Pharmacy, "Iuliu Haţieganu," Discipline of Legal Medicine, Cluj-Napoca, Romania; of L.C.H., Institut für Hämatopathologie Hamburg, Hamburg, Germany. 
activity of Il10 are discussed and explored for the treatment of widespread persistent viral infection in humans, such as chronic infection with hepatitis B virus or HIV. ${ }^{11}$

The downside of such therapeutic approaches would be the risk for promoting overshooting immune reactions by unleashing virus-specific effector cells. Surprisingly, the adverse effects of Il10 inhibition in the murine model of LCMV infection have not yet been addressed. The present study aims at quantitatively characterizing the sequelae of inhibiting Il10 during LCMV-induced immunopathology. The organ-specific pathology is mediated by virus-specific $\mathrm{CD} 8^{+}$and $\mathrm{CD}^{+}{ }^{-} \mathrm{T}$ lymphocytes and, thus, represents antigen-specific damage rather than collateral damage.

We report that a deficiency in Il10 further increases the already vigorous $\mathrm{T}$ cell-mediated immune response against LCMV, indeed accelerating virus elimination. However, the flipside of these effects is enhanced virusinduced immunopathology.

We observed that Il10-mediated immunoinhibitory activity is operative in both $\mathrm{C} 57 \mathrm{BL} / 6$ and $\mathrm{BALB} / \mathrm{c}$ - prototypic mouse strains of antipodal immunoregulatory activity characterized by type 1-biased versus type 2-biased cytokine milieus, respectively, in a variety of infectious diseases. ${ }^{12-14}$ We report a differential impact of Il10 on organ-specific immunopathology. Specifically, Il10 alleviates the LCMV-induced delayed-type hypersensitivity (DTH) footpad-swelling reaction as well as life-threatening choriomeningitis, whereas the fulminant viral hepatitis is not affected.

Taken together, these data show that Il10 is crucial for immunoregulation and for immunopathology in select tissues and organs during acute LCMV infection.

\section{Materials and Methods}

\section{Mice and Virus}

For this study, the following lines of mice were used: Il10deficient $\left(I l 10^{-1-}\right)$ mice of the C57BL/6 strain (kindly provided by Dr. Werner Müller, Institute for Genetics, Cologne, Germany) and of the BALB/c strain (a kind gift from Dr. Donna Rennick, DNAX, Palo Alto, CA $)^{15}$; perforin-deficient mice $\left(\right.$ Perf $^{-1-}$; kindly donated by Dr. Hans Hengartner, University of Zürich, Zürich, Switzerland) ${ }^{16}$; mice with LoxPflanked alleles of $I l 10\left(I l 10^{f l f t}\right.$; C57BL/6, kindly provided by Dr. Werner Müller; BALB/c, kindly provided by Dr. Axel Roers, Technical University, Dresden, Germany $)^{17}$; mice expressing Cre recombinase under control of the $C D 4$ promoter $\left(C D 4 C r e^{p o s} \text {; a kind gift from Dr. Axel Roers }\right)^{18}$ or of the $C D 11 c$ promoter $\left(\mathrm{CD} 11 \mathrm{Cr} e^{\text {pos }}\right.$; kindly donated by Dr. Boris Reizis, Columbia University, New York, NY). ${ }^{19}$ Mice were genotyped by end-point PCR analysis of tail biopsy samples, as published. ${ }^{15-19}$ All strains of mice were backcrossed at least 10 times to either the C57BL/6 or the BALB/c background. The mice were bred and kept strictly under barrier conditions and used when 8 to 12 weeks old. Experiments were performed in accordance with the Animal Protection
Law of Germany after approval by the Ethics Committee at the University of Cologne.

Throughout this study, the WE strain of LCMV was propagated and titrated as plaque-forming units on L929 cells, as described. ${ }^{20}$ When applicable, plaque-forming units were converted to mouse-infectious units (IU) by multiplication with the factor of 10, as published. ${ }^{21}$ Mice were infected with $10^{5} \mathrm{IU}$ i.v., $10^{6}$ i.p., $10^{3} \mathrm{IU}$ intracerebrally (i.c.), or $10^{5} \mathrm{IU}$ s.c. in the hind footpad, as indicated in the respective experiments. For the quantification of organ virus concentrations, weighed portions of organs were homogenized in phosphate-buffered saline and supplemented with $1 \%$ fetal calf serum and penicillin/streptomycin, and plaque-forming units on L929 cells were determined.

\section{Chromium-Release Assay}

Cytotoxic T-lymphocyte activity was measured according to Brunner et al, ${ }^{22}$ with modifications. ${ }^{23}$ Briefly, effector-cell populations were either single-cell suspensions of complete spleen cells or immunomagnetically enriched (MACS; Miltenyi Biotec, Gladbach, Germany) $\mathrm{CD} 8^{+}$lymphocytes (purity $>95 \%$ as determined by flow cytometry). These effector cells were incubated at graded densities with LCMV-infected or noninfected ${ }^{51} \mathrm{Cr}$-labeled SV40-transformed fetal fibroblastic C57BL/6-SV or BALB/c-SV target cells at $37^{\circ} \mathrm{C}$. After 4 hours, ${ }^{51} \mathrm{Cr}$ release was measured, and the percentage of lysis was calculated as:

$$
\begin{aligned}
\% \text { Lysis } & =\left(\mathrm{cpm}_{\text {experimental }}-\mathrm{cpm}_{\text {spontaneous }}\right) \\
& \times 100 /\left(\mathrm{cpm}_{\text {maximal }}-\mathrm{cpm}_{\text {spontaneous }}\right),
\end{aligned}
$$

where $c p m$ is counts per minute.

\section{Flow Cytometry}

Flow cytometry of splenic lymphocytes was performed according to standard procedures, using fluorescent monoclonal antibody (mAb) specific for CD4 (GK 1.5) or CD8 $\alpha$ (53-6.7) on a FACSCalibur cytometer (BD Biosciences, San Jose, CA). LCMV-specific $\mathrm{CD} 8^{+} \mathrm{T}$ cells were detected among the spleen cells of C57BL/6 or BALB/c mice by using phycoerythrinconjugated $\mathrm{H}-2 \mathrm{D}^{\mathrm{b}}$-dextramers loaded with either of the three $\mathrm{H}-2 \mathrm{D}^{\mathrm{b}}$-restricted immunodominant epitopes of LCMV $\left(\mathrm{GP}_{33-41}, \mathrm{GP}_{276-286}\right.$, or $\left.\mathrm{NP}_{396-404}\right)$ or with the $\mathrm{H}-2 \mathrm{~L}^{\mathrm{d}}$-restricted immunodominant epitope of LCMV $\left(\mathrm{NP}_{118-126}\right)$, respectively, according to the instructions of the manufacturer (Immudex, Copenhagen, Denmark).

\section{$\mathrm{CD}^{+}{ }^{\mathrm{T}} \mathrm{T}$-Cell Depletion}

CD4-specific mAbs were affinity-purified from supernatants of the rat hybridomas YTS191.1 and YTA3.1. ${ }^{24,25} \mathrm{~A}$ mixture of $250 \mu \mathrm{g}$ of each mAb was injected i.p. into mice on days $-4,-1,0$, and +1 related to the day of infection (day 0). Control mice were treated with purified rat $\mathrm{IgG}$ (Sigma-Aldrich, Taufkirchen, Germany). Depletion efficacy 
A

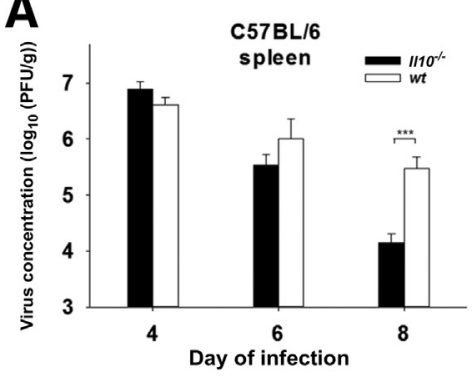

C

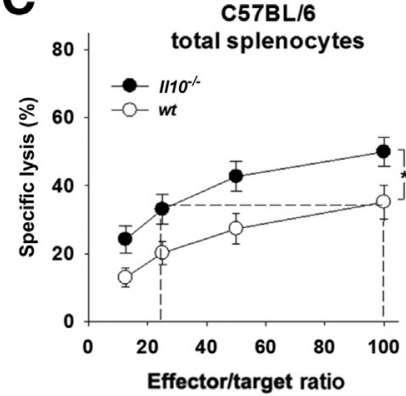

E

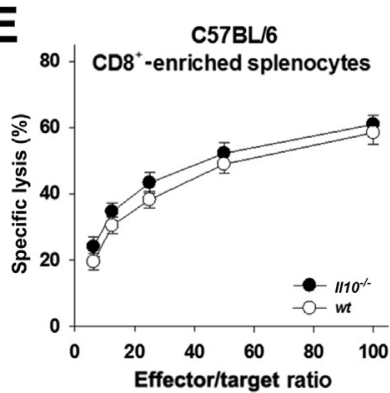

G

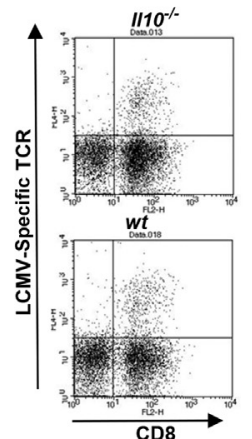

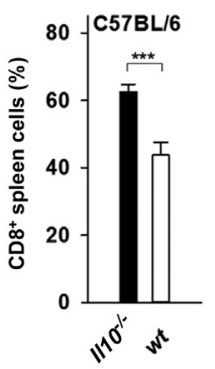
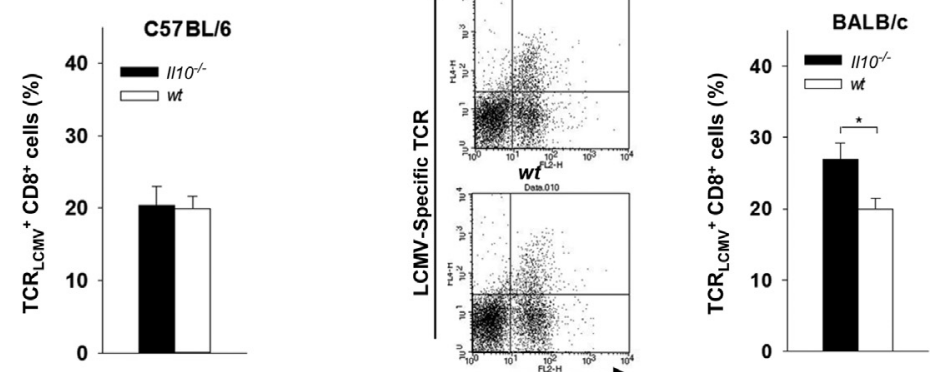
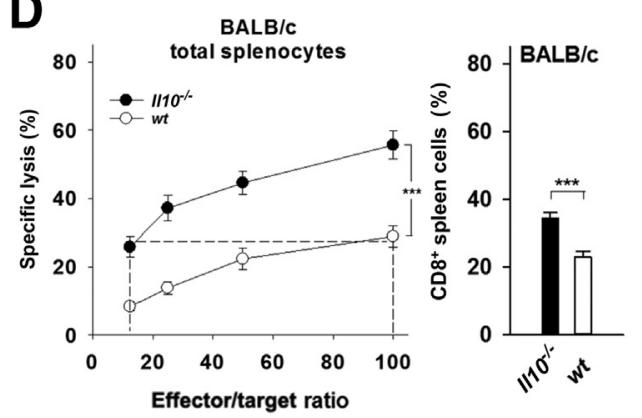

F

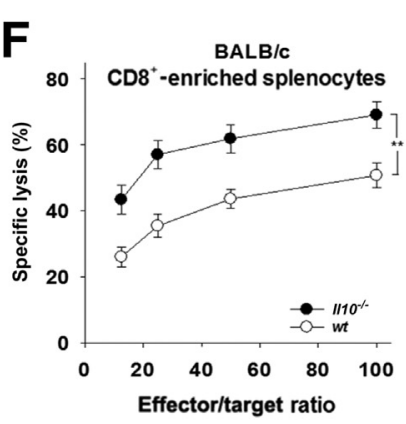

H

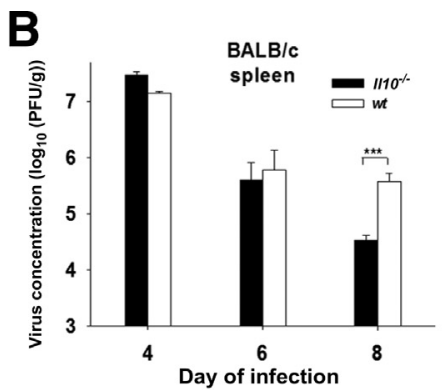

D

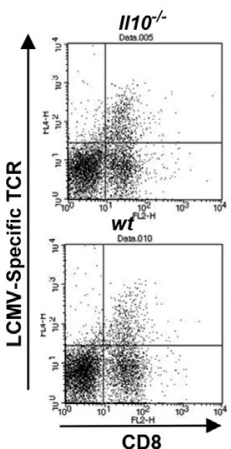

Figure 1 Effect of Il10 deficiency on the splenic immune response in $\mathrm{C} 57 \mathrm{BL} / 6$ and $\mathrm{BALB} / \mathrm{C}$ mice acutely infected with lymphocytic choriomeningitis virus (LCMV). A-H: $I l 10^{-1-}$ mice or wild-type (wt) littermates of the strains $\mathrm{C} 57 \mathrm{BL} / 6(\mathbf{A}, \mathbf{C}, \mathbf{E}$, and $\mathbf{G})$ and BALB/C $(\mathbf{B}, \mathbf{D}, \mathbf{F}$, and $\mathbf{H})$ were infected with $10^{5}$ mouseinfectious units (IU) of LCMV strain WE i.v. On the indicated days of infection, spleens were harvested to prepare organ homogenates (A and $\mathbf{B})$ or single-cell suspensions (C-H). A and B: Viral loads in the spleens on days 4, 6, and 8 of infection. C and D: LCMV-specific cytolytic activity of total spleenocytes in 4 -hour ${ }^{51} \mathrm{Cr}$ release assays against LCMV-infected syngeneic fibroblasts on day 8 of infection (left panels). Percentages of CD8 ${ }^{+}$cells among total lymphatic spleenocytes were determined by flow cytometry (right panels). E and F: LCMV-specific cytolytic activity of immunomagnetically enriched CD8 ${ }^{+}$spleen cells (purity $>95 \%$ ) against LCMV-infected syngeneic fibroblasts on day 8 of infection. $\mathbf{G}$ and $\mathbf{H}$ : Scatterplots show representative examples of staining for $\mathrm{H}-2 \mathrm{D}^{\mathrm{b}} / \mathrm{GP}_{33-41}(\mathbf{G})$ and $\mathrm{H}-2 \mathrm{~L}^{\mathrm{d}} / \mathrm{NP}_{118-126}(\mathbf{H})$ (left panels). Percentages of LCMV-specific CD8 ${ }^{+} \mathrm{T}$ cells within the effector-cell populations used in $\mathbf{C}$ and $\mathbf{D}$. LCMV-specific CD8 ${ }^{+} \mathrm{T}$ cells were detected by flow cytometry with major histocompatibility complex (MHC) dextramers loaded with LCMV-specific epitopes [MHC class I alleles and epitopes: $\mathrm{H}-2$ $D^{\mathrm{b}}$-restricted immunodominant epitopes $\mathrm{GP}_{33-41}, \mathrm{GP}_{276-286}$, and $\mathrm{NP}_{396-404}(\mathbf{G}), \mathrm{H}-2 \mathrm{~L}^{\mathrm{d}}$-restricted immunodominant epitope $\mathrm{NP}_{118-126}(\mathbf{H})$ ]. Percentages of $\mathrm{CD}^{+}$spleen cells expressing T-cell receptors (TCRs) for the three major immunodominant $\mathrm{H}-2 \mathrm{D}^{\mathrm{b}}$-restricted epitopes $\mathrm{GP}_{33-41}, \mathrm{GP}_{276-286}$, and NP $\mathrm{P}_{396-404}(\mathrm{G})$ and the immunodominant $\mathrm{H}-2 \mathrm{~L}^{\mathrm{d}}$-restricted epitope $\mathrm{NP}_{118-126}(\mathbf{H})$ (right panels). Data are expressed as means $\pm \mathrm{SEM}$ cumulative log ${ }_{10}$ values [in plaqueforming units (PFU) per gram] from two experiments on days 4 and 6 of infection (A and $\mathbf{B})$; from four (F) and five (C-E) experiments; from nine experiments on day 8 of infection (A); from 12 experiments on day 8 of infection (B); and as indicated in $\mathbf{C}$ and $\mathbf{D}(\mathbf{G}$ and $\mathbf{H}) . n=3(\mathbf{B}$, mice per genotype on days 4 and 6 of infection); $n=4$ (A, mice per genotype on days 4 and 6 of infection); $n=8$ (C, mice per genotype); $n=11$ (D, mice per genotype; $\mathbf{F}$, total mice per genotype); $n=13$ (E, total mice per genotype); $n=20$ (A, mice per genotype on day 8 of infection); $n=30$ (B, mice per genotype on day 8 of infection). ${ }^{*} P<0.05,{ }^{* *} P<0.01$, and ${ }^{* * *} P<0.001$ [pair-wise comparisons using the two-sample $t$-test for independent samples (two-sided)]. 
was verified by flow cytometry using the CD4-specific mAb GK 1.5.

\section{DTH Reaction}

LCMV was inoculated at a dose of $10^{5}$ IU s.c. into the right hind footpad. From day 5 of infection, the dorsoventral thickness of both hind feet was measured daily with spring calipers (Oditest, specially equipped with a soft spring; H.C. Kroplin GmbH, Schluchtern, Germany). Swelling is expressed as the factor with which the thickness of the inoculated foot exceeded the thickness of the contralateral noninoculated foot. ${ }^{26}$

\section{LCMV-Induced Hepatitis}

Mice were infected with LCMV $10^{6}$ IU i.p. On the indicated days, serum samples were prepared for the measurement of activity of the hepatic enzymes alanine aminotransferase and aspartate aminotransferase, with the appropriate test strips via the Reflotron Plus system according to the
A

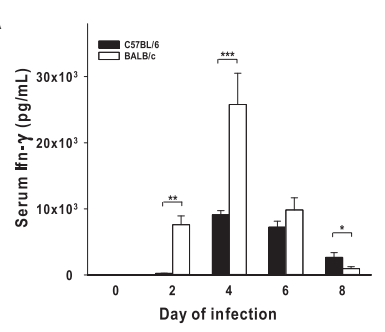

E

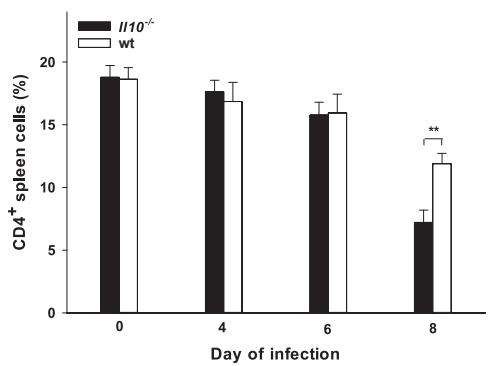

H

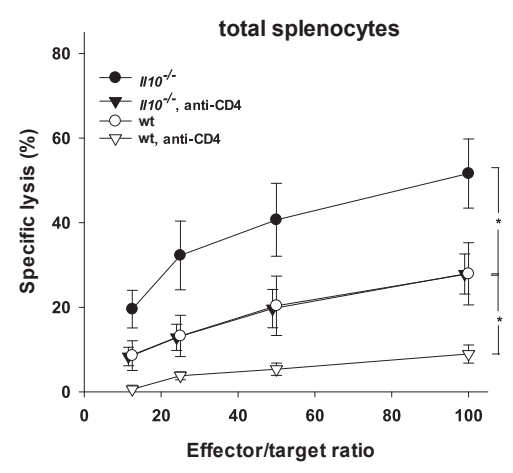

J

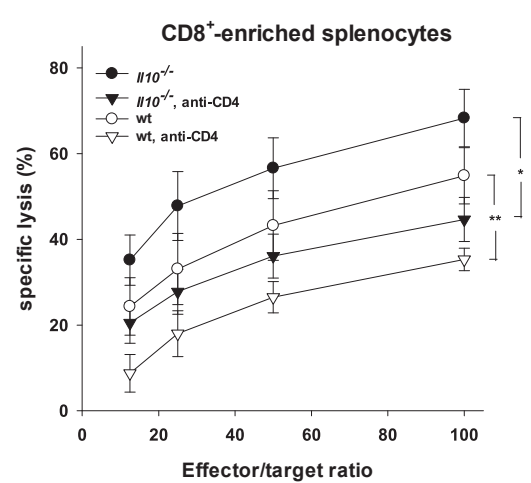

B

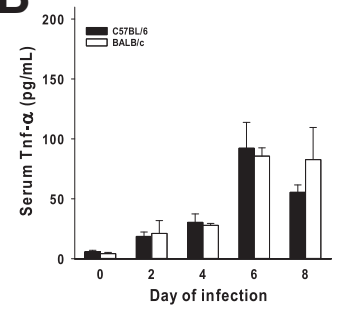

$\mathbf{F}$

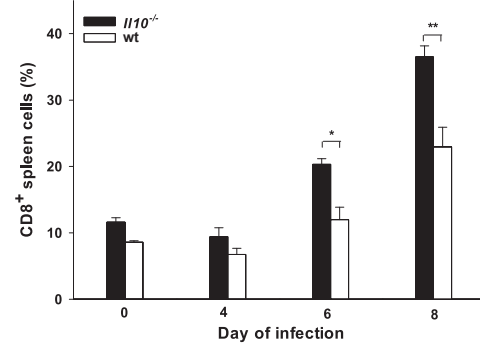

I

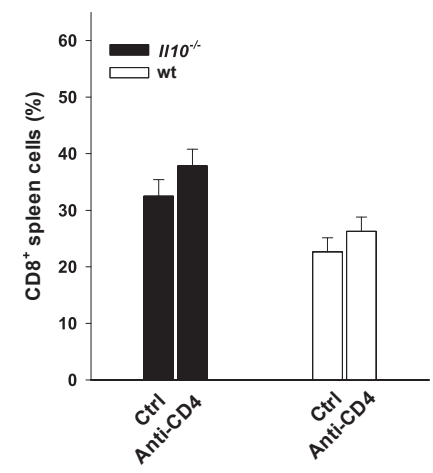

$\mathbf{K}$

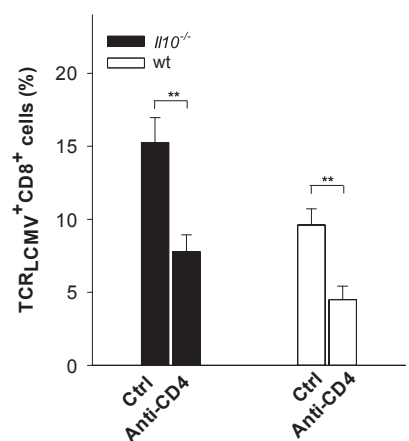

D
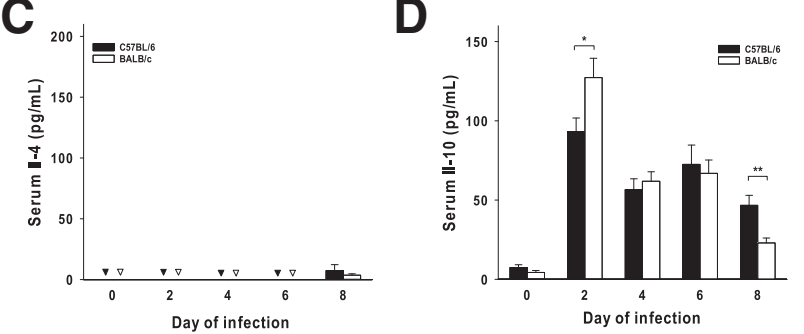

G

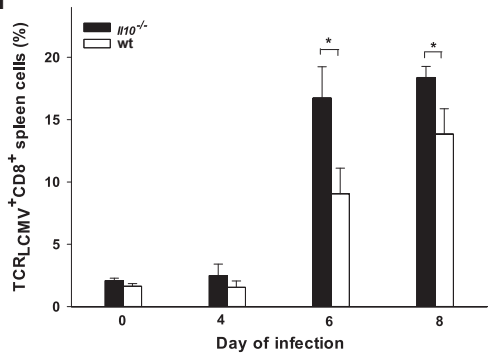

$\mathbf{L}$

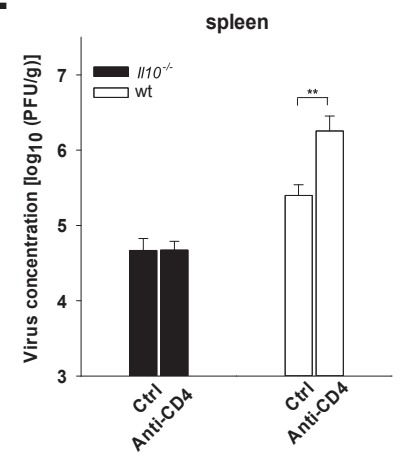


manufacturer's instructions (Roche Diagnostics Deutschland $\mathrm{GmbH}$, Mannheim, Germany).

Additionally, livers were prepared for histopathological analysis. After 24 hours of fixation in $4 \%$ buffered formalin, tissues were embedded into paraffin. Hepatic fibrosis was assessed on sections after Sirius staining. The inflammatory activity [ie, periportal or periseptal interface hepatitis, confluent necrosis, focally (spotty) lytic necrosis, apoptosis, focal inflammation, and portal inflammation] was assessed according to the Ishak score in hematoxylin and eosin-stained samples. ${ }^{27}$

\section{Clinical Course and Histopathology of LCMV}

After injection of LCMV $10^{3}$ IU i.c., mice were monitored for clinical symptoms daily over the indicated observation periods.

For brain histopathology and immunohistochemistry analysis, mice were intracardially perfused with $\mathrm{NaCl}$ while under deep $\mathrm{CO}_{2}$ anesthesia. Brains were prepared and processed to yield frozen and paraffin sections, as described. ${ }^{28}$ Paraffin sections were stained with hematoxylin and eosin and with Luxol fast blue with cresyl violet, respectively. Immunohistochemistry analysis was performed on cryopreserved specimens by use of the avidin-biotin complex technique with appropriate biotinylated secondary antibodies (Vectastain Elite Kit; Vector Laboratories, Burlingame, CA). Peroxidase reaction product was visualized using 3,3-diaminobenzidine (Sigma-Aldrich) as chromogen and $\mathrm{H}_{2} \mathrm{O}_{2}$ as cosubstrate, with the following monoclonal rat anti-mouse antibodies: CD8 $\alpha$ (clone 53-6.7), CD45 (clone M1/9.3.4.HL.2), and major histocompatibility complex class II antigen (I-Ab,d,q haplotypes; clone M5/114.15.2).

For semiquantitative evaluation of meningitis and ventriculitis, a grading system was introduced, as follows: 0 , no infiltrates; + , single inflammatory cells; ++ , small infiltrates of inflammatory cells, not exceeding one layer of lymphocytes; and +++ , large infiltrates of inflammatory cells, exceeding one layer of lymphocytes. The slides were assessed independently by two pathologists (A.B. and M.D.) in a blinded fashion.

\section{Quantification of Cytokines in Sera}

In serum samples, concentrations of Il10, interferon (Ifn)- $\gamma$, Il4, and tumor necrosis factor (Tnf) were quantified either by specific enzyme-linked immunosorbent assay ( $R \& D$ Systems, Abingdon, UK) or by the LEGENDplex Mouse Th1/Th2 Panel (BioLegend, San Diego, CA) according to the instructions of the manufacturers.

\section{Statistical Analysis}

Data on continuous variables were summarized by means \pm SD or SEM. Groups were compared using the two-sample $t$-test for independent samples (two-sided). Figure legends report the number of mice studied per group.

Serial measurements of the intensity of the DTH reaction, or $\operatorname{Tnf} \alpha$ and Ifn $\gamma$ concentrations, were analyzed using the area under the curve as a summary measure. Area under the curve was divided by the individual duration of the measurement period to account for different observation times due to early deaths. Data are presented by course of means over time.

Survival times after infection are displayed using KaplanMeier curves. Groups were compared using the log-rank test, and point-wise $95 \%$ CIs for survival probability were calculated.

A two-sided probability value of $<0.05$ was considered statistically significant, although no adjustment for multiplicity was made. Statistical analyses were performed using the IBM SPSS Statistics software package version 22.0 (IBM Corp., Armonk, NY).

\section{Results}

\section{Il10 Deficiency Enhances CD8 ${ }^{+}$T-Cell Responses and Accelerates Virus Elimination during Acute LCMV Infection}

Antigen-specific T-cell responses are generally enhanced by type 1-biased and inhibited by type 2-biased $\mathrm{T}$ cell-derived cytokine milieus present during the induction and maturation of the effector cells. In some infection

\footnotetext{
Figure 2 Systemic cytokine pattern and influence of CD4 ${ }^{+}$T cells on the expansion and cytotoxic activity of lymphocytic choriomeningitis virus (LCMV)-specific CD8 ${ }^{+}$ T cells in $I\left(10^{-1-}\right.$ mice. Mice were infected with $10^{5}$ mouse-infectious units (IU) of LCMV strain WE i.v. A-D: Th1 versus Th2 lead cytokines were quantified in the serum of wild-type (wt) C57BL/6 and BALB/c mice. Concentrations of interferon (Ifn)- $\gamma$ (A), tumor necrosis factor (Tnf) (B), Il4 (C), and Il10 (D). E-L: From Il10 ${ }^{-1-}$ and wt littermates of the BALB/c strain, spleens were harvested to prepare single-cell suspensions on the indicated days of infection. The percentages of $\mathrm{CD} 4^{+}$cells $(\mathbf{E})$, total $\mathrm{CD}^{+}$cells $(\mathbf{F})$, and LCMV-specific T-cell receptors (TCR $\left.\mathrm{TCMV}^{+}\right) \mathrm{CD}^{+}$cells among lymphatic spleen cells $(\mathbf{G})$ were determined by flow cytometry. $\mathbf{H}$ and $\mathrm{J}$ : Groups of mice were depleted of $\mathrm{CD}_{4}{ }^{+} \mathrm{T}$ cells by i.p. injection of $500 \mu \mathrm{g}$ CD4-specific monoclonal antibody or control (Ctrl) with normal rat IgG on days $-4,-1,0$, and +1 related to the day of infection (day 0). On day 8 of infection, LCMV-specific cytolytic activity of total spleen cells (H) or of immunomagnetically enriched CD8 ${ }^{+}$spleen cells (purity $>95 \%$ ) $(\mathbf{J})$ was determined in 4-hour ${ }^{51} \mathrm{Cr}$ release assays against LCMV-infected BALB/c fibroblasts. I: The percentage of $C D 8^{+} \mathrm{T}$ cells among lymphatic spleen cells was determined by flow cytometry. K: Percentages of TCR ${ }_{L C M V}^{+} C D 8^{+} T$ cells among lymphatic spleen cell populations were determined by flow cytometry with $\mathrm{H}-2 \mathrm{~L}^{\mathrm{d}}$ major histocompatibility complex (MHC)-dextramers loaded with the LCMV-derived immunodominant epitope $\mathrm{NP}_{118-126}$. L: Homogenates were prepared from segments of the spleens used in I to determine the viral load in the spleens on day 8 of infection. Data are expressed as means \pm SEM cumulative values from two (A-C), three (K), or four (D and I) experiments; as cumulative values from two experiments on days 0 to 6 of infection and from three experiments on day 8 of infection (E- $\mathbf{G})$; as means \pm SEM values from four experiments ( $\mathbf{H}$ and $\mathbf{J})$; and as means \pm SEM $\log _{10}$ values [in plaque-forming units (PFU) per gram] (L). $n \geq 3$ (A-D, mice per day and experiment on days 3,4 , and 6 of infection); $n=4\left(\mathbf{E}-\mathbf{G}\right.$, mice per genotype on days 0 to 6 of infection; $\mathbf{H}$ and $\mathbf{J}$, control-treated $I\left(10^{-/-}\right.$and wt mice); $n \geq 4$ (A-D, mice per day and experiment on days 0 and 8$) ; n=5$ ( $\mathbf{H}$ and $\mathbf{J}$, anti-CD4-treated wt mice) $; n=6\left(\mathbf{E}-\mathbf{G}\right.$, mice per genotype on day 8 of infection; $\mathbf{K}$, control-treated $I\left(10^{-/}-\right.$and wt mice); $n=8(\mathbf{H}$ and $\mathbf{J}$, anti-

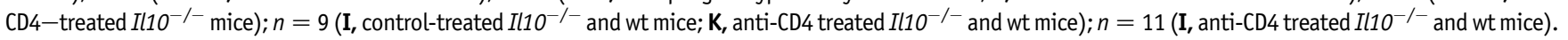
${ }^{*} P<0.05,{ }^{* *} P<0.01$, and ${ }^{* * *} P<0.001$ [pair-wise comparisons using the two-sample $t$-test for independent samples (two-sided)].
} 
A
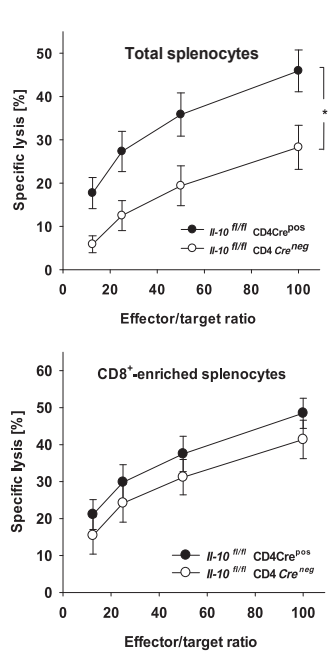

C
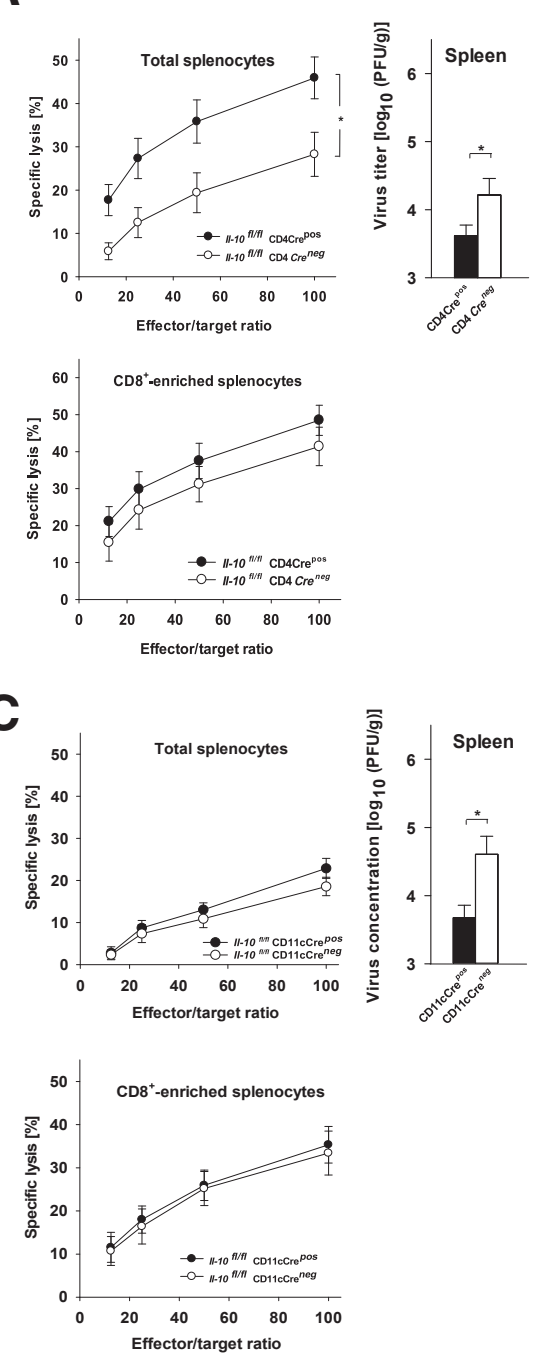

B
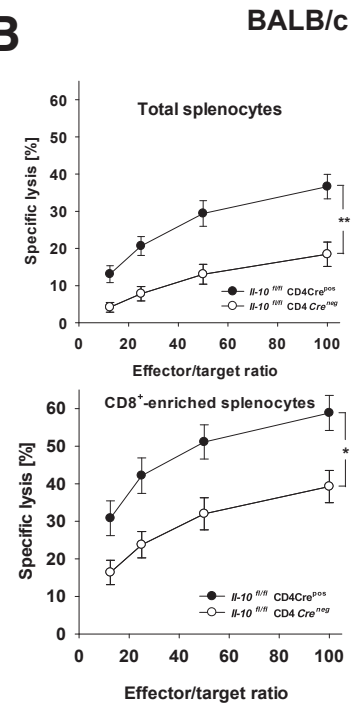

D
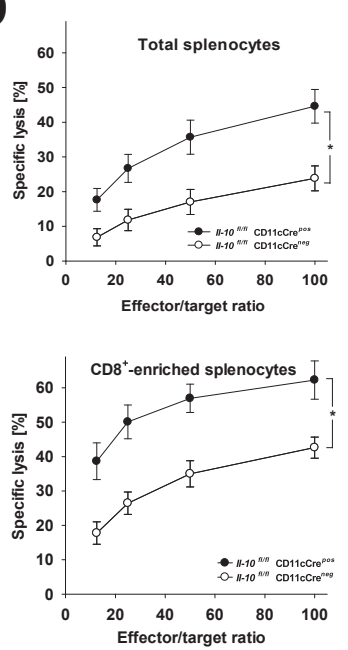
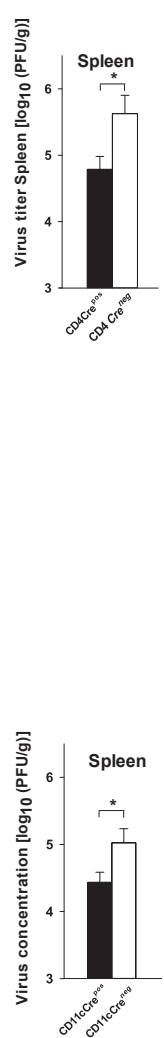

Figure 3 Identification of the cellular source of Il10-dampening lymphocytic choriomeningitis virus (LCMV)-specific $\mathrm{CDB}^{+}$T-cell responses. C57BL/6 (A and C) or BALB/C (B and $\mathbf{D}$ ) mice were infected with $10^{5}$ plaque-forming units (PFU) of LCMV strain WE i.v. LCMV-specific cytolytic activity of splenic single-cell suspensions prepared from mice with cell type-specific deficiency of Il10 in T lymphocytes (Il10 $0^{f / f l} / \mathrm{CD} 4 \mathrm{Cre} e^{\text {pos; }}$ A and B) or in dendritic cells $\left(I l 10^{f l / f l} / C D 11 c C r e^{\text {pos }} ; \mathbf{C}\right.$ and $\left.\mathbf{D}\right)$ and their respective $I l 10^{f l f l} / C D 4 C r e^{\text {neg }}$ littermates. Shown is the specific cytolytic activity of total spleen cells or immunomagnetically enriched $\mathrm{CD} 8^{+}$ spleen cells (purity of $\mathrm{CD}^{+}$cells $>95 \%$ ) as determined in 4 -hour ${ }^{51} \mathrm{Cr}$ release assays against LCMV-infected syngeneic fibroblasts on day 8 of infection. Additionally, splenic viral loads were determined. Data are expressed as means \pm SEM cumulative values from three (B and C), four (D), or five experiments (A). $n=5\left(\mathbf{D}, I l 10^{f l f l} / C D 11 c C r e^{n e g}\right)$; $n=6\left(\mathbf{B}, I l 10^{f l f l} / \mathrm{CD} 4 \mathrm{Cre} e^{\text {neg }} ; \mathbf{C}, I l 10^{f l f l} / \mathrm{CD} 11 \mathrm{CCre} e^{\text {neg; }}\right.$; D, Il1 $\left.0^{f l / f l} / \mathrm{C} 11 \mathrm{CCr} e^{p o s}\right) ; n=7$ (C, Il1 $\left.{ }^{f l f f} / \mathrm{C} 11 \mathrm{CC} e^{\text {pos }}\right)$; $n=10\left(\mathbf{B}, I l 10^{f l f l} / \mathrm{CD} 4 \mathrm{Cre} e^{\text {pos }}\right) ; n=14\left(\mathbf{A}, I l 10^{f / f l}\right)$ $\mathrm{CD} 4 \mathrm{Cre} \mathrm{Ceg}^{\text {neg }}$ and $\mathrm{I}\left(10^{f l f f} / \mathrm{CD} 4 \mathrm{Cr} \mathrm{C}^{\text {pos }}\right) .{ }^{*} P<0.05$, ${ }^{*} P<0.01$ (pair-wise comparisons between $\mathrm{Cre}^{\text {pos }}$ and $\mathrm{Cre}^{\text {neg }}$ mice using the two-sample $t$-test for independent samples). models, C57BL/6 mice have been identified as type 1 -biased responders, whereas $\mathrm{BALB} / \mathrm{c}$ mice are more prone to type $2-$ biased immune responses. ${ }^{12-14}$ Therefore, the influence of $\mathrm{Il10}$ on the course and strength of the LCMV-induced, T cell-mediated immunopathology was characterized in the $1110^{-1-}$ mice of both the C57BL/6 and the BALB/c strains.

In the $\mathrm{C} 57 \mathrm{BL} / 6$ and $\mathrm{BALB} / \mathrm{c} I l 10^{-1-}$ mice infected with LCMV strain WE $10^{5}$ IU i.v., the kinetics of virus elimination were significantly accelerated as compared with those in the respective wild-type (wt) littermates (Figure 1, A and B).

Because virus-specific $\mathrm{CD}^{+} \mathrm{T}$ cells are necessary and sufficient for eliminating LCMV during acute primary infection, ${ }^{29}$ the effects of $\mathrm{Il10}$ on $\mathrm{CD}^{+} \mathrm{T}$ cells were characterized in greater detail. The LCMV-specific cytotoxic activity of total spleen cells from the C57BL/6 or BALB/c $I l 10^{-1-}$ mice was significantly stronger than that of total spleen cells from the respective wt littermates (Figure 1, C and D). This increase was about twofold stronger in the $\mathrm{BALB} / \mathrm{c}$ than in the $\mathrm{C} 57 \mathrm{BL} / 6$ mice, as assessed using the effector/target ratios required for achieving a defined degree of lysis (Figure 1, C and D).

The cytotoxic activity of total spleen cell preparations depends on the percentage of $\mathrm{CD}^{+} \mathrm{T}$ cells among total spleen cells and on the percentage of LCMV-specific T cells within the population of $\mathrm{CD}^{+} \mathrm{T}$ cells. In both mouse strains, the enhanced LCMV-specific cytotoxic activity of total spleen cells from the $1 l 10^{-1-}$ mice was accompanied by a significantly increased percentage of $\mathrm{CD}^{+} \mathrm{T}$ cells among the spleen cells on day 8 of infection (Figure 1, C and D).

The LCMV-specific cytotoxicity of enriched $\mathrm{CD}^{+} \mathrm{T}$ cells was not altered in the C57BL/6 $\mathrm{Il10} \mathrm{O}^{-1-}$ mice compared with the wt mice (Figure $1 \mathrm{E}$ ). In contrast, enriched $\mathrm{CD} 8^{+} \mathrm{T}$ cells from the BALB/c $I l l 0^{-1-}$ mice exerted substantially greater specific cytolysis than did the corresponding wt control $\mathrm{CD}^{+} \mathrm{T}$ cells (Figure $\left.1 \mathrm{~F}\right)$.

The percentages of cells with $\mathrm{T}$-cell receptors specific for LCMV ( $\mathrm{TCR}_{\mathrm{LCMV}^{+}}{ }^{+}$) among CD8 ${ }^{+} \mathrm{T}$ cells did not differ in spleens of the $\mathrm{C} 57 \mathrm{BL} / 6 \mathrm{IllO} \mathrm{O}^{-1-}$ mice versus the wt mice (Figure $1 \mathrm{G})$. In contrast, the BALB/c $I l 10^{-1-}$ mice had substantially greater percentages of $\mathrm{TCR}_{\mathrm{LCMV}}{ }^{+}$cells among $\mathrm{CD} 8^{+}$ 

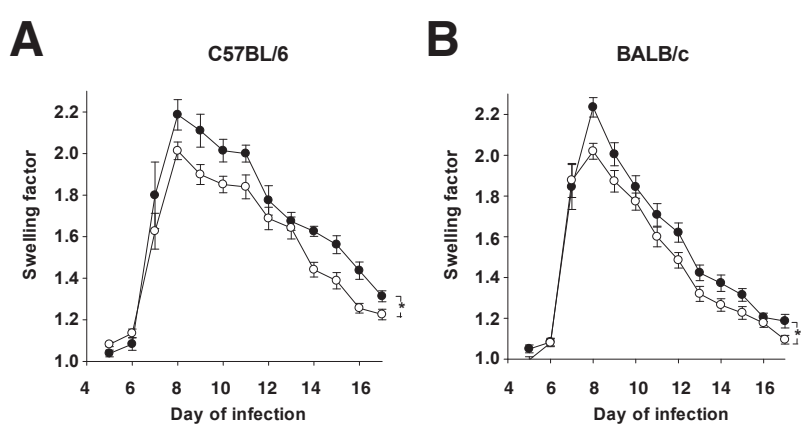

Figure 4 Effect of Il10 deficiency on the lymphocytic choriomeningitis virus (LCMV)-specific delayed-type hypersensitivity reaction. Il10 ${ }^{-/-}$mice (closed circles) or wild-type (wt) littermates (open circles) of the C57BL/6 (A) or $\mathrm{BALB} / \mathrm{C}(\mathrm{B})$ strain were infected by s.c. injection of $10^{5}$ mouse-infectious units (IU) of LCMV strain WE into the right hind footpad. Footpad swelling was measured at 24-hour intervals and is shown as the swelling factor with which the dorsoventral thickness of the inoculated foot exceeded that of the contralateral, non-inoculated foot. Serial measurements on the footpad swelling were analyzed using the area under the curve (AUC) as a summary measure. Data are expressed as cumulative values from three (A) or four (B) experiments. $n=12\left(\mathbf{A}, \mathrm{I} l 10^{-/}\right) ; n=15$ (A, wt); $n=17$ (B, wt); $n=19$ (B, Ill1 ${ }^{-1-}$ ). ${ }^{*} P<0.05$ (specific values: $\mathrm{C} 57 \mathrm{BL} / 6, P=0.012 ; \mathrm{BALB} / \mathrm{C}, P=0.017$; two-sample $t$-test).

cells in spleens than did their wt littermate controls (Figure 1H). Biologically most relevant are the frequencies of $\mathrm{TCR}_{\mathrm{LCMV}}{ }^{+}$ $\mathrm{CD}^{+} \mathrm{T}$ cells among total splenic lymphocytes, because these frequencies directly correlate with the probabilities of encounters between LCMV-specific effector cells and LCMV-infected target cells. Calculations according to the formula:

$$
\begin{aligned}
& \left(\text { Percentage of } \mathrm{CD}^{+} \text {spleen cells }\right) \\
& \quad \times\left(\text { Percentage of } \mathrm{TCR}_{\mathrm{LCMv}}{ }^{+} \mathrm{CD} 8^{+} \mathrm{T} \text { cells }\right) / 100
\end{aligned}
$$

revealed that in the $1110^{-1-}$ mice of both strains, the frequencies of $\mathrm{TCR}_{\mathrm{LCMV}}{ }^{+} \mathrm{CD} 8^{+} \mathrm{T}$ cells among total spleen cells are greater than those in the respective wt control mice and that frequencies are 1.5- to 2-fold greater in the C57BL/6 mice than in the corresponding BALB/c genotype (C57BL/6 mice: $1110^{-/-}$, approximately $12.8 \%$; wt, approximately $8.7 \%$; BALB/c mice: $1110^{-/-}$, approximately $9.3 \%$; wt, approximately $4.6 \%$ ).

All together, increased frequencies of $\mathrm{TCR}_{\mathrm{LCMV}}{ }^{+} \mathrm{CD} 8^{+}$ $\mathrm{T}$ cells are accompanied in spleens of $1110^{-/-}$mice of the $\mathrm{C} 57 \mathrm{BL} / 6$ as well as the BALB/c strains by accelerated virus clearance during acute LCMV infection as compared to the respective wt controls.

\section{$\mathrm{CD}^{+} \mathrm{T}$ Cells Support Expansion and Cytotoxic Activity of LCMV-Specific CD8 ${ }^{+}$T Cells in $\mathrm{Il}_{10^{-/-}}$Mice}

In acute LCMV infection of mice, $\mathrm{CD} 4^{+} \mathrm{T}$ cells are not essential for the generation of an effective virus-specific immune response. ${ }^{29}$ However, $\mathrm{CD} 4^{+} \mathrm{T}$ cells are strongly activated and support the generation of LCMV-specific memory $\mathrm{CD}^{+} \mathrm{T}$ cells (reviewed by Wiesel and Oxenius ${ }^{30}$ ). During acute LCMV infection, the pattern of the prototypic Th1 cytokines, Ifn $\gamma$ and Tnf (Figure 2, A and B), versus Th2 cytokines, Il4 and Il10 (Figure 2, C and D), did not allow for the classification of C57BL/6 mice as typical Th1 responders versus BALB/c mice as typical Th2 responders, as reported for various infections. ${ }^{12-14,31}$ On the contrary, serum levels of Ifn $\gamma$ were much greater in the $\mathrm{BALB} / \mathrm{c}$ mice than in the $\mathrm{C} 57 \mathrm{BL} / 6$ mice during the early days of infection (Figure 2A). Remarkably, the greatest serum levels of Il10 were detected in both strains of mice as early as 2 days of infection (Figure 2D).

$\mathrm{CD}^{+}{ }^{+}$T-helper cells are major producers of the immunoregulatory cytokine Il10. This raised the question of whether the enhancing effect of deleting the single cytokine Il10 might obviate the helper effect of $\mathrm{CD}^{+} \mathrm{T}$ cells on the generation of strong, LCMV-specific, $\mathrm{CD} 8^{+} \mathrm{T}$ cell-mediated immune responses. Experiments addressing this question were performed in $\mathrm{BALB} / \mathrm{c}$ mice after we observed a more pronounced effect of Il10 on the LCMV-specific response of spleen cells from this mouse strain (Figure 1).

$\mathrm{CD}^{+} \mathrm{T}$ cells were present at similar frequencies in the spleens of the BALB/c $\mathrm{IllO}^{-1-}$ and wt mice from days 0 to 6 of infection with LCMV (Figure 2E). However, between days 6 and 8 of infection, the frequencies of $\mathrm{CD}^{+} \mathrm{T}$ cells dropped significantly in the $1110^{-1-}$ mice, to about $40 \%$ less than those in the wt mice. This finding is in contrast to those of $\mathrm{CD}^{+} \mathrm{T}$ cells (Figure 2F) and LCMV-specific $\mathrm{CD} 8^{+} \mathrm{T}$
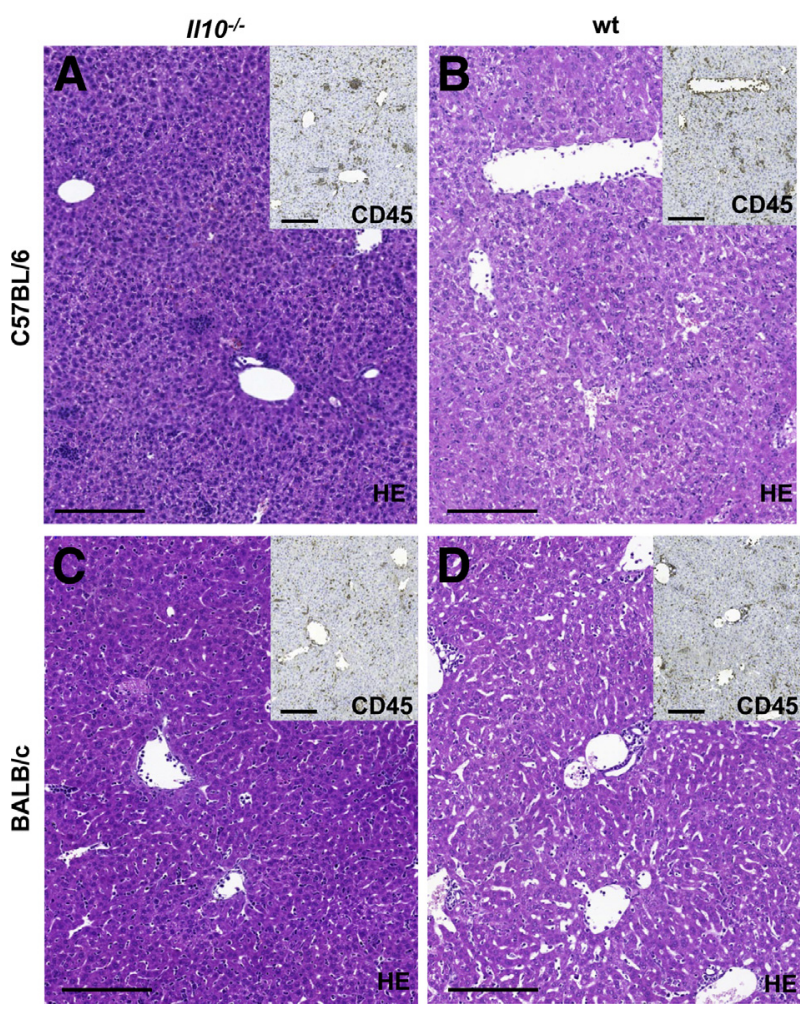

Figure 5 Hepatic lesions in $\mathrm{Il}_{10^{-/-}}$and wild-type (wt) mice on day 8 of infection with lymphocytic choriomeningitis virus (LCMV) i.p. Il10-/- mice (A and $\mathbf{C}$ ) or wt littermates (B and $\mathbf{D}$ ) of the C57BL/6 (A and B) or BALB/C (C and D) strain were infected by injection with LCMV strain WE $10^{6}$ mouse-infectious units (IU) i.p. On day 8 of infection, serial sections of the liver were subjected to either standard hematoxylin and eosin (HE) staining or to immunostaining with CD45-specific monoclonal antibodies (insets). Scale bars: $200 \mu \mathrm{m}$. 
cells (Figure $2 \mathrm{G}$ ), the frequencies of which were greater in the spleens of the BALB/c $I l 10^{-1-}$ mice than in those of the wt mice. Thus, there is divergence in the population dynamics of splenic $\mathrm{CD}^{+}$and $\mathrm{CD}^{+} \mathrm{T}$ cells in $\mathrm{BALB} / \mathrm{c}$ $1 l 10^{-1-}$ mice compared with those in their wt littermates. We asked whether $\mathrm{CD} 4^{+} \mathrm{T}$ cells have a particular impact on the effector functions of $\mathrm{CD}^{+} \mathrm{T}$ cells in LCMV-infected $\mathrm{IlIO}^{-1-}$ mice, and we depleted the $\mathrm{CD}^{+} \mathrm{T}$ cells in those mice. Depletion of $\mathrm{CD}^{+}{ }^{+} \mathrm{T}$ cells reduced the LCMV-specific cytolytic activity of total spleen cells from the BALB/c $I l 10^{-/-}$

\section{C57BL/6}

A

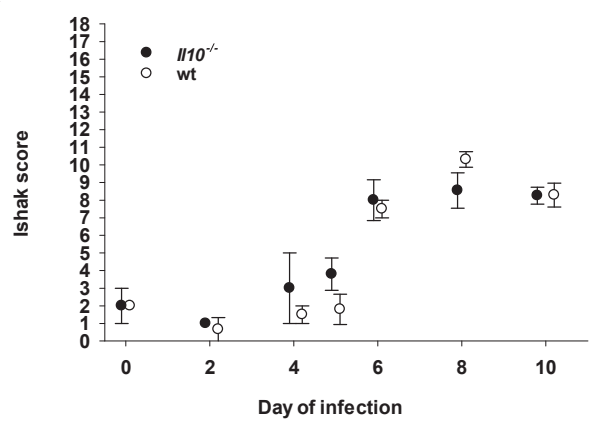

B

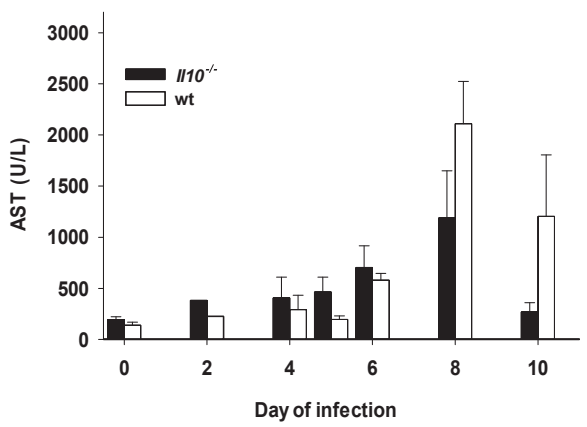

C
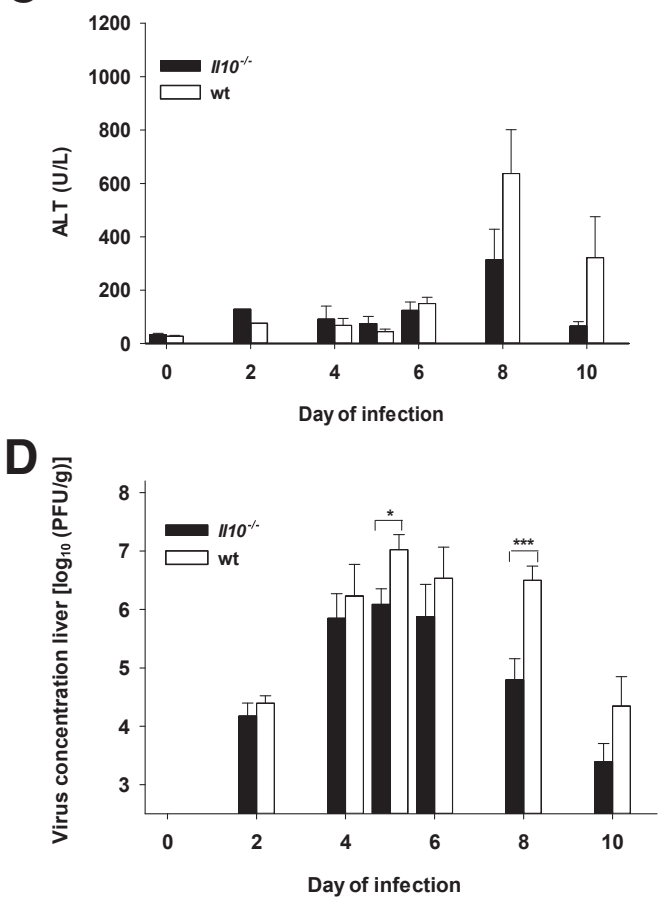

and the wt mice on day 8 of infection (Figure $2 \mathrm{H}$ ). The reduced cytolytic activity did not coincide with reduced frequencies of $\mathrm{CD}^{+} \mathrm{T}$ cells in total spleen cells (Figure 2I). However, it has to be considered that the depletion of $\mathrm{CD} 4^{+} \mathrm{T}$ cells per se skews the proportion of $\mathrm{CD}^{+} \mathrm{T}$ cells among total spleen cells to greater percentages. This impediment in the quantitative assessment of $\mathrm{CD}^{+}{ }^{+} \mathrm{T}$-cell activity was bypassed by further analysis of immunomagnetically enriched $\mathrm{CD}^{+} \mathrm{T}$ cells.

The LCMV-specific cytolytic activity of the enriched $\mathrm{CD}^{+} \mathrm{T}$ cells from the $1110^{-/-}$and wt mice depleted of

BALB/C
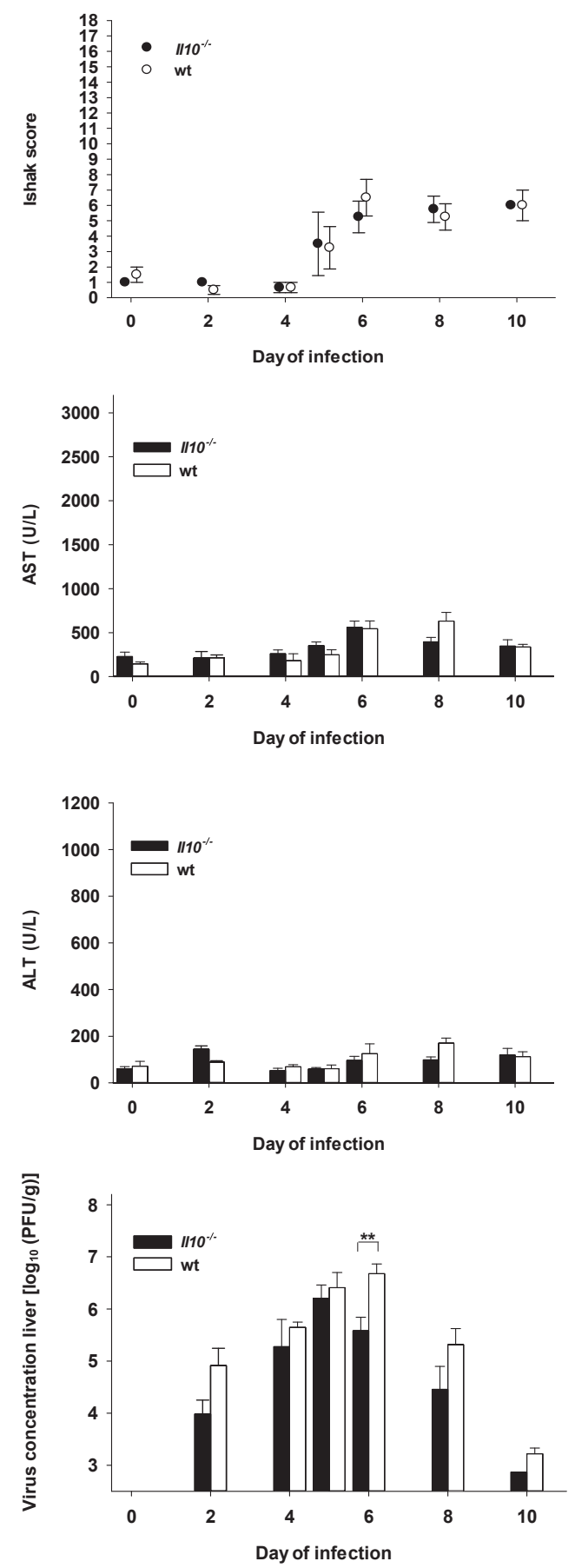
$\mathrm{CD} 4^{+} \mathrm{T}$ cells was significantly reduced compared with those in the respective control-treated littermates (Figure 2J). Concurrently, in both the $1 l 10^{-1-}$ and the wt mice, the depletion of $\mathrm{CD}^{+}{ }^{+} \mathrm{T}$ cells was associated with a significantly reduced frequency of splenic $\mathrm{TCR}_{\mathrm{LCMV}}{ }^{+} \mathrm{CD} 8^{+} \mathrm{T}$ cells to about $50 \%$ of the levels observed in the respective controltreated littermates (Figure 2K). Collectively, with regard to $\mathrm{CD} 8^{+}$-enriched spleen cells, cytolytic activity and percentages of LCMV-specific CD8 ${ }^{+} \mathrm{T}$ cells concordantly were greatest in the control-treated $I l 1 \mathrm{O}^{-1-}$ mice. Both parameters reached similar intermediate levels in both the $\mathrm{CD}^{+} \mathrm{T}$ cell-depleted $1110^{-1-}$ mice and the control-treated $\mathrm{wt}$ mice, whereas the lowest levels were detected in the $\mathrm{CD} 4^{+}$ $\mathrm{T}$ cell-depleted wt mice.

Despite its effect on the expansion and ex vivo cytolytic activity of LCMV-specific $\mathrm{CD}^{+} \mathrm{T}$ cells, the depletion of $\mathrm{CD} 4^{+} \mathrm{T}$ cells did not affect the viral load in the spleens of the $I l 10^{-1-}$ mice by day 8 of infection (Figure 2L). In contrast, in the wt mice it resulted in a significantly greater viral load than that in the control-treated littermates.

Taken together, although Il10 deficiency diminishes the splenic $\mathrm{CD} 4^{+} \mathrm{T}$-helper cell population during acute LCMV infection, the direct impact of 1110 deficiency on $\mathrm{CD}^{+} \mathrm{T}$ cells overrides a possible effect of this reduction in T-helper cell frequencies.

\section{Identification of the Il10-Producing Cell Type Crucial for Down-Modulating the LCMV-Specific Immune Response}

Systemic levels of Il10 were detected at peak levels already at 2 days of infection and slowly declined thereafter in both the C57BL/6 and the BALB/c mice (Figure 2D). For a thorough understanding of the Il10-dependent immunoregulatory circuits in acute LCMV infection, we aimed at identifying the Il10producing cell type(s) that suppress the LCMV-specific CD8 ${ }^{+}$ $\mathrm{T}$ cell response.

Various myeloid and lymphoid cell types have been shown to produce Il10 during acute and chronic LCMV infection. ${ }^{32}$ During acute LCMV infection, assumedly the two candidate cell types that produce Il10 are Tlymphocytes and dendritic cells
(DCs), ${ }^{33-35}$ because $\mathrm{T}$ cells are the effector cells necessary and sufficient for control of the virus, and DCs are necessary for inducing virus-specific $\mathrm{T}$ cells. To assess the effect of $\mathrm{Il10}$ produced by either T cells or DCs, we used LoxP/Cre technology to generate mice with cell type-specific deficiency in Il10.

In the C57BL/6 strain, T cell-specific Il10 deficiency $\left(\mathrm{C} 57 \mathrm{BL} / 6 \mathrm{Ill} / \mathrm{O}^{A / f} / \mathrm{CD} 4 \mathrm{Cr} e^{\text {pos }}\right.$ ) was associated with increased LCMV-specific cytolytic activity of total spleen cells compared with that in the corresponding wt controls (C57BL/6 $1110^{f / f /} /$ $\mathrm{CD} 4 \mathrm{Cr} e^{\text {neg }}$; Figure $3 \mathrm{~A}$ ). This difference was almost abolished when immunomagnetically enriched splenic $\mathrm{CD} 8^{+} \mathrm{T}$ cells were used as effector cells (Figure 3A). In contrast, in the BALB/c strain, both total spleen cells as well as $\mathrm{CD} 8^{+}$-enriched effector cells from the $\mathrm{BALB} / \mathrm{c} I l 10^{f / f} / \mathrm{CD} 4 \mathrm{Cr} e^{\text {pos }}$ mice exerted significantly greater cytolysis than did cells from BALB/c $I l 10^{f / f /} /$ $C D 4 C r e^{\text {neg }}$ littermates (Figure 3B). The splenic viral load was significantly lower in $I 110^{A / H} / C D 4 C r e^{p o s}$ mice than in $I l 10^{A / H} /$ $\mathrm{CD} 4 \mathrm{Cre}^{\text {neg }}$ controls of both the C57BL/6 and BALB/c strains (Figure 3, A and B).

In the C57BL/6 strain, DC-specific Il10 deficiency

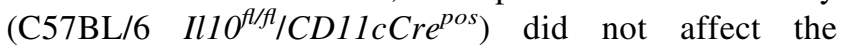
LCMV-specific cytolytic activity of either total or CD8 ${ }^{+}$ $\mathrm{T}$ cell-enriched spleen cells (Figure $3 \mathrm{C}$ ). In contrast, both total as well as $\mathrm{CD} 8^{+} \mathrm{T}$ cell-enriched spleen cells from $\mathrm{BALB} / \mathrm{c}$ mice with $\mathrm{DC}$-specific Il10 deficiency $\left(\mathrm{BALB} / \mathrm{c} \quad 1110^{f / f} / \mathrm{CD} 11 \mathrm{cCr} e^{\text {pos }}\right.$ ) were associated with significantly stronger LCMV-specific cytolysis than were the respective effector cells from the corresponding control littermates (Figure 3D). Notably, the splenic viral load was

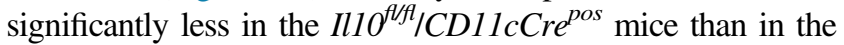
$1110^{A / A} / \mathrm{CD} 11 \mathrm{CCr} e^{\text {neg }}$ mice of the C57BL/6 as well as the $\mathrm{BALB} / \mathrm{c}$ strains (Figure 3, C and D).

Taken together, T cell-derived Il10 suppresses the LCMVinduced immune response, as assessed by the LCMV-specific cytolytic activity of spleen cells. In the BALB/c mice, but not in the C57BL/6 mice, DC-derived Il10 contributes significantly to this effect. Nonetheless, T cell-specific deficiency as well as DC-specific deficiency in Il10 lead to reduced splenic viral loads in both the C57BL/6 and the $\mathrm{BALB} / \mathrm{c}$ strains.

\footnotetext{
Figure 6 Course of the lymphocytic choriomeningitis virus (LCMV)-induced hepatitis in Il10 ${ }^{-/}$mice and wild-type (wt) littermates. A-D: Il10 ${ }^{-/-}$mice and wt littermates of the C57BL/6 strain (left panels) or the BALB/c strain (right panels) were infected with i.p. injection of $10^{6}$ mouse-infectious units (IU) of LCMV strain WE. On the indicated days of injection, tissue samples and sera were prepared. A: Hepatitis activity was assessed in a blinded fashion according to Ishak scores on micrographs of hematoxylin and eosin-stained liver samples. B and C: Activity of aspartate aminotransferase (AST; B) and alanine aminotransferase (ALT; C) in serum samples prepared on the indicated days of infection. D: Viral load in the liver. Data are expressed as means \pm SEM cumulative values from one experiment (B and $\mathbf{C}, C 57 \mathrm{BL} / 6$ mice on day 2$)$, two experiments $(\mathrm{A}, \mathrm{C} 57 \mathrm{BL} / 6$ mice on days 0,2 , and 4 and $\mathrm{BALB} / \mathrm{C}$ mice; $\mathbf{B}$ and $\mathbf{C}, \mathrm{C} 57 \mathrm{BL} / 6$ mice on days 0 and 4 and BALB/C mice on days 2 and 4 ), three experiments (A,C57BL/6 mice on days 5, 6, and 10; B and $\mathbf{C}, C 57 B L / 6$ mice on day 5 and BALB/C mice on day 0$)$, or four experiments (A, C57BL/6 mice on day 8; $\mathbf{B}$ and $\mathbf{C}, \mathrm{C} 57 \mathrm{BL} / 6$ and $\mathrm{BALB} / \mathrm{c}$ mice on days 6,8 , and 10$)$; or as means \pm SEM cumulative $\log _{10}$ values [in plaque-forming units (PFU) per gram] from two experiments (D, C57BL/ 6 mice on days $2,4,5$, and 6 and $B A L B / c$ mice on days $2,4,5,6$, and 10$)$, three experiments (D, BALB/c mice on day 8$)$, four experiments (D, C57BL/6 mice on day 10), or five experiments (D, C57BL/6 mice on day 8$) . n=1$ (B and C, C57BL/6 mice per genotype on day 2$) ; n=2(\mathbf{A}, \mathbf{C} 57 \mathrm{BL} / 6$ mice per genotype on days 0 and 4 and $B A L B / C$ mice per genotype on days 0 and $10 ; \mathbf{B}$ and $\mathbf{C}, C 57 B L / 6$ mice per genotype on day $4 ; \mathbf{D}, B A L B / c$ mice per genotype on days 5 and $10) ; n=3$ (A, C57BL/6 mice per genotype on day 2; B and C, BALB/c mice per genotype on day 4; D, C57BL/6 and BALB/c mice per genotype on days 2 and 4$) ; n=4$ (A, C57BL/6 mice per genotype on day 6 and BALB/c mice per genotype on any day other than days 0 and 10; $\mathbf{B}$ and $\mathbf{C}, \mathrm{C} 57 \mathrm{BL} / 6$ mice per genotype on day 0 and BALB/ c mice per genotype on day 5; D, C57BL/ 6 mice per genotype on days 5 and 6 and BALB/c mice per genotype on day 6$) ; n=5$ (A-C, C57BL/6 mice per genotype on day 5; B and C, BALB/c mice per genotype on day 2$) ; n=7$ (A, C57BL/ 6 mice per genotype on day 10; D, C57BL/6 Il $10^{-/-}$mice on day 10 and BALB/C mice per genotype on day 8$) ; n=8$ (B and C, C57BL/6 mice per genotype on days 6,8 , and 10$) ; n=8$ to 11 (B and $\mathbf{C}, \mathrm{BALB} / \mathrm{c}$ mice per genotype on days $0,6,8$, and $10) ; n=10(\mathbf{D}, \mathrm{C} 57 \mathrm{BL} / 6$ wt mice on day 10$) n=11\left(\mathbf{D}, \mathrm{C57BL} / 6 \mathrm{I} / 10^{-/-}\right.$mice on day 8$) ; n=12(\mathbf{D}, \mathrm{C} 57 \mathrm{BL} / 6$ wt mice on day 8$) ; n=13(\mathbf{A}, \mathrm{C} 57 \mathrm{BL} / 6 \mathrm{mice}$ per genotype on day 8 ). ${ }^{*} P<0.05,{ }^{*} P<0.01$, and ${ }^{* * *} P<0.001$ (pair-wise comparisons using the two-sample $t$-test for independent samples).
} 


\section{C57BL/6}

A

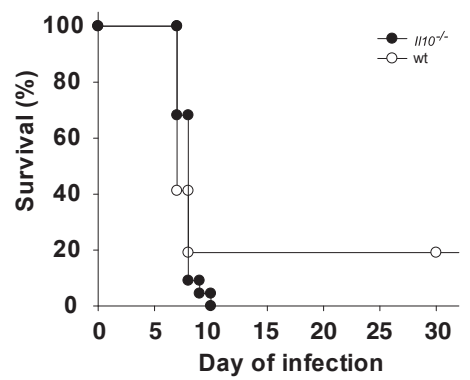

B

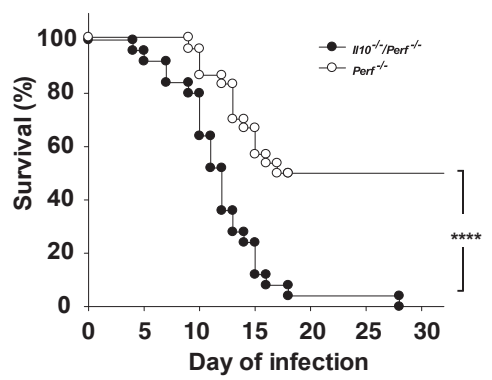

BALB/c

C

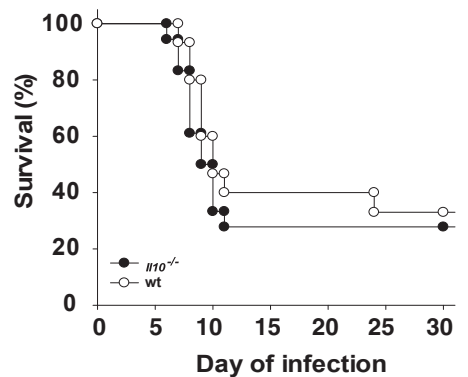

E

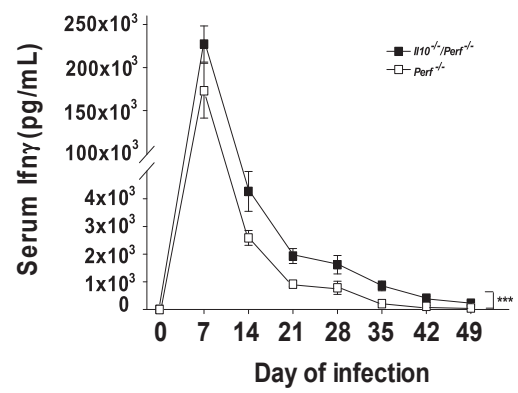

D

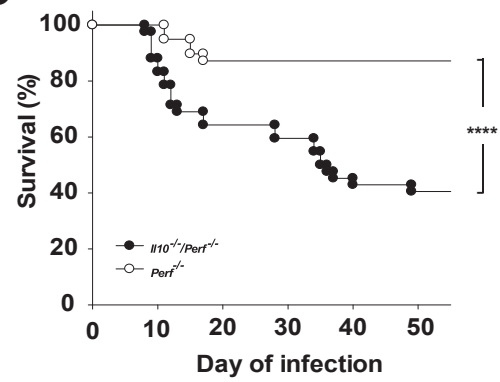

$\mathbf{F}$

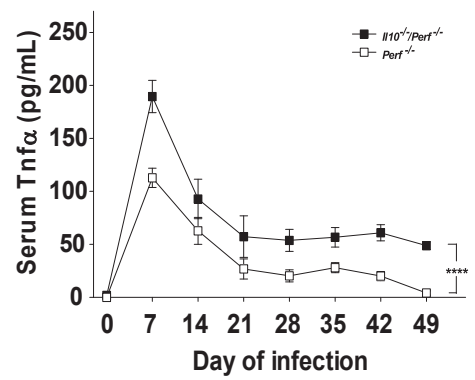

Figure 7 Effects of Il10 deficiency on the course of meningitis after intracerebral infection with lymphocytic choriomeningitis virus (LCMV). $\mathrm{Il}_{10^{-/-}}$, Perf ${ }^{--}$, or $\mathrm{I} 110^{-/-} / \mathrm{Perf}^{-/-}$mice or wild-type (wt) littermates of the C57BL/6 (A and B) or BALB/C (C-F) strain were infected by intracerebral injection of $10^{3}$ mouse-infectious units (IU) of LCMV strain WE. Clinical appearance and survival of the mice were observed daily. Survival after infection is shown using KaplanMeier curves. A and C: $\mathrm{I}\left(10^{-/-}\right.$mice versus wt littermates of the $\mathrm{C} 57 \mathrm{BL} / 6$ strain $(\mathbf{A})$ and the BALB/C strain (C). Day-14 survival rates $(95 \%$ CI): $\mathrm{C} 57 \mathrm{BL} / 6$ : $\mathrm{Il10^{-/ }}, 0(0-0)$ versus wt, $17.6 \%$ $(0-35.8) ; P=0.930$ (A); BALB/c: Il1 $10^{-/-}, 28.6 \%$ (4.9-52.3) versus wt, $41.7 \%(13.8-69.5) ; P=$ 0.504 (C). B and D: $I 110^{-/-} /$Perf $^{-/-}$doubledeficient mice versus Perf ${ }^{-1}$ mice of the $\mathrm{C} 57 \mathrm{BL} / 6$ strain (B) and the BALB/C strain (D). Day-21 survival rates (95\% CI): C57BL/6: Il10-/- $/$ Perf ${ }^{-1}, 24.0 \%$ (7.3-40.7) versus Perf ${ }^{-1}, \quad 66.7 \% \quad(49.8-$ 83.6) (B); BALB/C: Il10 ${ }^{-/-} /$Perf $^{-/-}, 87.5 \%$ (77.397.7) versus Perf ${ }^{-/}, 65.9 \%$ (52.0-79.8) (D). E and F: Serum concentrations of the proinflammatory cytokines interferon (Ifn) $-\gamma(\mathbf{E})$ and tumor necrosis factor (Tnf) (F) in the BALB/c Perf ${ }^{-/}$and

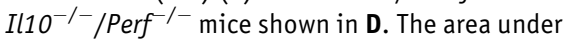
the curve (AUC, weighted by the individual duration) was used as a summary measure. Data are expressed as cumulative values from three (A and $\mathbf{C}$ ) or four (B and $\mathbf{D}$ ) experiments, or as means \pm SEM cumulative values from randomly chosen mice from two experiments (E and $\mathbf{F}$ ). $n=4\left(\mathbf{E}\right.$ and $\mathbf{F}, \mathrm{Il}_{10^{-/}}{ }^{-}$Perf $^{-/-}$mice on days on days $\geq 8) ; n=8$ (E and $\mathbf{F}$, Perf $^{-1-}$ mice on days $\left.\geq 8\right)$; $n=10$ (E and $\mathbf{F}$, Perf $^{-/}{ }^{-}$mice on day 7$) ; n=11$ (E and $\mathbf{F}$, Il $^{-10^{-/}} /$Perf $^{-/-}$mice on day 7 ); $n=12$ (wt, C); $n=14\left(\right.$ Il $\left.10^{-/-}, \mathbf{C}\right) ; n=17$ (wt, A); $n=22\left(\right.$ Il10 $\left.0^{-/-}, \mathbf{A}\right) ; n=25\left({\text { Il } 10^{-/} / \text {Perf }}^{-/-}, \mathbf{B}\right)$; $n=30\left(\right.$ Perf $\left.^{-/-}, \mathbf{B}\right) ; n=40\left(\right.$ Perf $^{-/}$, , D) $; n=$ $44 \quad$ Il1 $10^{-1-} /$ Perf $^{-1-}$, D). ${ }^{* * * P}<0.001$, $* * * * P<0.0001$ [log-rank test (A-D); twosample $t$-test (E and $\mathbf{F}$ )].
Il10 Dampens LCMV-Specific Immunopathology in Select Organs

Depending on the route of virus inoculation, the noncytopathic LCMV induces various $\mathrm{T}$ cell-mediated immunopathological syndromes in acutely infected immunocompetent adult mice; for example, s.c. inoculation of LCMV into the hind footpad induces a DTH reaction, ${ }^{26}$ i.p. injection leads to acute hepatitis, ${ }^{36}$ and i.c. inoculation results in fatal choriomeningitis. ${ }^{37} \mathrm{We}$ addressed all of these manifestations for the immunoregulatory effects of Il10.

\section{LCMV-Induced DTH Reaction}

The typical course of the DTH reaction induced on intraplantar inoculation of $\mathrm{LCMV}^{26}$ was similar between the $1110^{-1-}$ mice and the wt littermates of the C57BL/6 strain (Figure 4A) and the BALB/c strain (Figure 4B). The intensity of the DTH reaction was enhanced with moderate significance in the $1110^{-1-}$ mice of both strains.

These data suggest that Il10 contributes to regulating the DTH reaction on acute LCMV infection.

\section{LCMV-Induced Acute Hepatitis}

Acute hepatitis after i.p. injection of LCMV was monitored by both histopathology (Figures 5 and $6 \mathrm{~A}$ ) and by serum aminotransferase measurements (Figure 6, B and C). In contrast to the DTH reaction, Il10 did not have an impact on the course of LCMV-induced acute hepatitis in the C57BL/6 or in the $\mathrm{BALB} / \mathrm{c}$ mice. Nonetheless, the viral load in the liver was less in the $\mathrm{C} 57 \mathrm{BL} / 6$ as well as in the $\mathrm{BALB} / \mathrm{c} I l 10^{-1-}$ mice compared with those in the respective wt littermates (Figure 6D).

\section{LCMV-Induced Choriomeningitis}

The kinetic properties and mortality rate of fatal choriomeningitis ensuing from i.c. LCMV infection were similar 

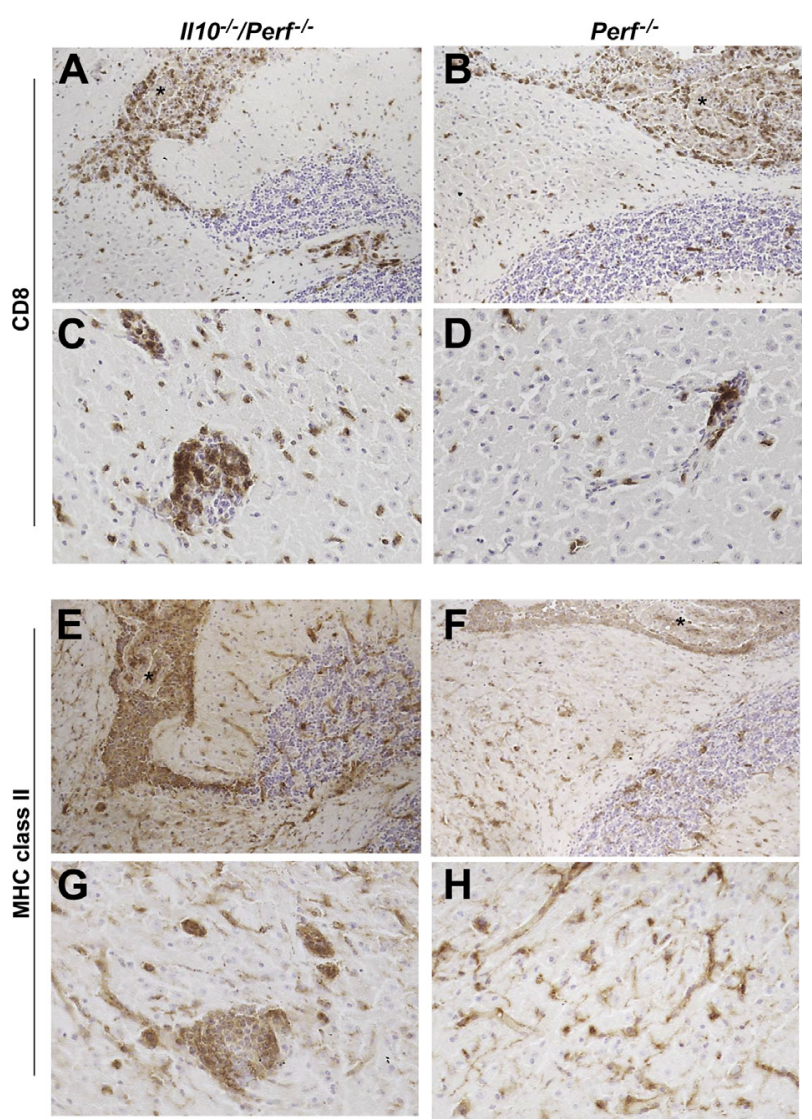

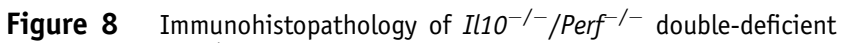
mice versus $P_{\text {erf }}{ }^{--}$mice after intracerebral infection with lymphocytic choriomeningitis virus (LCMV). BALB/C Il10 ${ }^{-/-} / \operatorname{Perf}^{-/-}$(A, C, D, and G) mice and Perf $^{-1-}$ littermates $(\mathbf{B}, \mathbf{D}, \mathbf{F}$, and $\mathbf{H})$ were intracerebrally infected with $10^{3}$ mouse-infectious units (IU) of LCMV strain WE. At day 15 of infection, mice were euthanized to prepare the brains for immunohistological analysis. Slides were stained with rat anti-mouse CD8 (A-D) or rat anti-mouse major histocompatibility complex (MHC) class II antigen (E-H) and were slightly counterstained with hemalum. A-D: Prominent infiltrates of $\mathrm{CD}^{+}$lymphocytes in the basal meninges, the fourth ventricle (asterisks), and perivascularly in a BALB/C Il10 ${ }^{-/-} /$Perf $^{-/-}$mouse (A and C) are shown; in contrast, fewer $\mathrm{CD}^{+} \mathrm{T}$ cells are present in a BALB/C Perf ${ }^{-1}$ mouse (B and $\left.\mathbf{D}\right)$. E-H: Microglial activation, as evidenced by up-regulation of MHC class II antigen, is much more pronounced in a BALB $/ \mathrm{C} \mathrm{Il10}^{-/} / \mathrm{Perf}^{-/-}$mouse (E and G) compared with a BALB/C Perf ${ }^{\prime-}$ mouse (F and $\left.\mathbf{H}\right)$. Original magnification: $\times 200($ A, B, E, and F); $\times 400($ C, D, G, and H).

between the $1110^{-1-}$ mice and the wt littermates of both the C57BL/6 and BALB/c strains (Figure 7, A and C).

In contrast to this fulminant fatal immunopathology in immunocompetent mice, a subacute wasting disease develops in mice with impaired $\mathrm{CD}^{+} \mathrm{T}$ cell-mediated cytotoxicity, such as in $\operatorname{Perf}^{-1-}$ mice, ${ }^{16}$ with i.c. LCMV infection. The double-deficient $I l 10^{-1-} / \mathrm{Perf}^{-1-}$ mice succumbed to i.c. LCMV infection significantly earlier and at greater rates than did the Il10-proficient/Perf ${ }^{-1-}$ control mice of the $\mathrm{C} 57 \mathrm{BL} / 6$ as well as the $\mathrm{BALB} / \mathrm{c}$ strains (Figure 7, B and D), once again indicating the immunoregulatory effect of Il10. However, the C57BL/6 and BALB/ c mice showed major differences in the kinetics of LCMVinduced fatality. In the C57BL/6 mice, almost all of the
$I l 10^{-1-} /$ Perf $^{-1-}$ mice as well as the Perf $^{-1-}$ control mice died between days 5 and 15 of infection (Figure 7B), whereas in the BALB/c mice, about half of the $1 l 10^{-1-} /$ Perf $^{-1-}$ mice died between 15 and 40 days of infection (Figure 7D). Concurrent with this long-lasting course of disease, serum concentrations of $\operatorname{Tnf}$ and $\operatorname{Ifn} \gamma$ were significantly greater in the BALB/c $I l 10^{-1-} / \mathrm{Perf}^{-1-}$ than in the Perf $^{-1-}$ littermates during the entire course of infection (Figure 7, E and F). This finding is in accordance with the view that proinflammatory cytokines are involved in causing the LCMV-induced wasting disease in mice with compromised cytotoxic T-lymphocyte activity. ${ }^{38}$

Brains of i.c. infected mice were histopathologically analyzed on day 15 of infection, that is, when no more fatalities were observed in the BALB/c Perf ${ }^{-1}$ mice, whereas the $\mathrm{BALB} / \mathrm{c} I l 10^{-1-} / \mathrm{Perf}^{-1-}$ mice were amid the fatal phase of meningitis. At that time, in mice of both genotypes, LCMVinduced basal meningitis and ventriculitis were obvious by histological examination (Figure 8, A and B). Severe meningitis and ventriculitis, dominated by $\mathrm{CD}^{+} \mathrm{T}$ cells (Figure $8 \mathrm{~A}$ ), with lymphocytes also having infiltrated the periventricular parenchyma (Figure 8C), had developed in the $I l 10^{-1-} / \mathrm{Perf}^{-1-}$ mice (Table 1). In contrast, meningitis and ventriculitis were mild in the Perf $^{-1-}$ littermates (Figure 8, B and D, and Table 1). Ubiquitous cerebral inflammation was also evidenced by the activation of microglia as detected by up-regulation of the major histocompatibility complex class II antigen in those cells. Similar to the lymphocytic infiltrates, microglia activation was more prominent in the $1 l 10^{-1-} /$ Perf $^{-1-}$ mice (Figure 8, E and G) than in the Perf ${ }^{-1-}$ littermates (Figure 8, F and $\mathrm{H})$. By day 20 of infection, CNS inflammation in both genotypes regressed (data not shown). Nonetheless, meningeal, ventricular, and parenchymal $\mathrm{CD}^{+} \mathrm{T}$ cells were still more numerous and microglial activation was still more pronounced in the $1110^{-1-}$ Perf $^{-1-}$ mice than in the Perf ${ }^{-1-}$ mice.

Taken together, in i.c. LCMV-infected Perf ${ }^{-1-}$ mice, Il10 deficiency markedly enhances both cerebral inflammation and systemic levels of proinflammatory cytokines.

In contrast to CNS inflammation, in the same mice shown in Figure 8, the severity of the concomitant hepatitis, ensuing from the systemic spreading of LCMV after i.c. inoculation, was similar between the $\mathrm{BALB} / \mathrm{c} \quad 1 l 10^{-1-} / \mathrm{Perf}^{-1-}$ mice

Table 1 Semiquantitative Evaluation of Inflammatory Infiltrates in the Meninges and the Ventricles on Day 15 of Intracerebral Infection with Lymphocytic Choriomeningitis Virus

\begin{tabular}{lll}
\hline & \multicolumn{2}{l}{ Mouse type } \\
\cline { 2 - 3 } Anatomical site & Il10 ${ }^{-/-} /$Perf $^{-/-}$ & Perf $^{-/-}$ \\
\hline Meninges & $+++^{*}$ & ++ \\
Ventricle & +++ & + \\
\hline
\end{tabular}

$n=5$ per genotype.

*0: no infiltrates.

+ , single inflammatory cells; ++ , small infiltrates of inflammatory cells, not exceeding one layer of lymphocytes; +++ , large infiltrates of inflammatory cells, exceeding one layer of lymphocytes. 
(means \pm SEM Ishak score, $9.33 \pm 0.47$ ) and the Perf $^{-1-}$ mice $(9.0 \pm 0.81)$ by day 15 of infection. These data confirm and extend our observations that Il10 does not affect the severity of LCMV-induced hepatitis (Figure 6A), regardless of whether $\mathrm{CD}^{+} \mathrm{T}$ cells are competent for perforin-mediated cytotoxicity. Furthermore, this finding indicates that, within the same mouse, the intensity of organ-specific immunopathology depends on both the activity of immune cells and the particular susceptibility of the respective organ.

\section{Discussion}

Persistent LCMV infection in mice is associated with impaired T-cell responses secondary to up-regulated Il10. Accordingly, blocking of II10 action resulted in restored T-cell function and the elimination of the virus. ${ }^{9,10}$ Using the mouse model of acute LCMV infection, here we characterize the immunopathology resulting from T-cell responses in $I l 10^{-/-}$mice.

Consistent with previous observations from several other groups using various LCMV strains, ${ }^{9,10}$ we report that LCMV strain WE infection was more effectively controlled in $I l 10^{-/-}$than in wt mice during the first days of infection.

We now show that Il10 deficiency leads to enhanced immunopathology in select organs, indicating a price of the potential therapeutic use of blocking Il10 for the treatment of viral infections.

\section{No Typical Th1 or Th2 Pattern in C57BL/6 or BALB/C Mice during Acute LCMV Infection}

Most studies on LCMV-specific immune responses are performed in mice of the C57BL/6 strain. In various models of infection, this strain has been shown to be genetically disposed to generate a type 1-skewed cytokine milieu resulting in a particularly strong cellular $\mathrm{CD} 8^{+} \mathrm{T}$ cell-mediated immune response. ${ }^{12-14}$ The BALB/c strain has been shown to be the prototypic immunoregulatory antipode of the $\mathrm{C} 57 \mathrm{BL} / 6$ strain because it is genetically disposed to generating a type 2-skewed cytokine pattern supportive of humoral rather than cell-mediated immune responses. Notably, Il10 belongs to the array of type 2 cytokines. During acute LCMV infection, systemic levels of Th1 and Th2 lead cytokines were not differentially skewed in C57BL/6 versus BALB/c mice according to a Th1- versus Th2-biased pattern. On the contrary, exceptionally high serum levels of the Th1 lead cytokine, Ifn $\gamma$, were detected in BALB/c mice during the early days of LCMV infection. This finding advises caution with regard to generalizing even widely accepted results to specific models.

\section{$\mathrm{CD}^{+}{ }^{+}$Cells in Acute LCMV Infection: Helper versus Immunoregulatory Effects}

Classic $\mathrm{CD} 4^{+} \mathrm{T}$ cells, functionally termed $T$ helper cells, support the generation of $\mathrm{CD}^{+}$cytotoxic $\mathrm{T}$ cells in many viral infections, including LCMV infection. ${ }^{39}$ But then CD4 ${ }^{+}$ $\mathrm{T}$ cells are also known as major producers of the immunoregulatory cytokine Il10, which is true also during-at least persistent-LCMV infection. ${ }^{9,10}$ This finding raised the question of whether and to which quantitative degree the complex helper effect of $\mathrm{CD}^{+}{ }^{+} \mathrm{T}$ cells and the regulatory effect of the single cytokine Il10 together fine-tune the virus-specific activity of $\mathrm{CD}^{+} \mathrm{T}$ cells during acute LCMV infection. The enhanced virus-specific cytotoxic activity observed in $\mathrm{CD}^{+} \mathrm{T}$ cells from $\mathrm{BALB} / \mathrm{c} I l 10^{-1-}$ mice was repressed by $\mathrm{mAb}$-mediated depletion of $\mathrm{CD}^{+} \mathrm{T}$ cells in $\mathrm{BALB} / \mathrm{c} 1110^{-1-}$ mice to the level observed with $\mathrm{CD} 8^{+} \mathrm{T}$ cells from control-treated wt mice. The comparison of the outcomes of these two completely different treatment approaches, that is, genetic deletion of a single cytokine versus mAb-mediated depletion of a complete cell population, may appear as comparing apples to oranges. Nonetheless, the comparison of the effects of these different treatments on the same readout provides an impression of the regulatory power of Il10 on $\mathrm{CD}^{+} \mathrm{T}$ cells even during this very strong antiviral immune response.

Another important aspect of the Il10-mediated immunoregulatory circuitry is the cellular source of Il10, which may be secreted by many immunological cell types but also nonimmunological cell types (reviewed by Moore et $\mathrm{al}^{1}$ and $\mathrm{O}^{\prime}$ Garra et $\mathrm{al}^{2}$ ). Using cell type-specific knockout mice, we revealed $\mathrm{T}$ lymphocytes as the most relevant source of Il10 dampening cytotoxic activity of $\mathrm{CD}^{+} \mathrm{T}$ cells in C57BL/6 as well as in BALB/c mice during acute LCMV infection. Additionally, DCs were identified as a source of Illo dampening of LCMV-specific cytotoxic $\mathrm{CD} 8^{+} \mathrm{T}$ cells in $\mathrm{BALB} / \mathrm{c}$ mice but not in C57BL/6 mice. Remarkably, DC-derived Il10 had a similar impact on the viral load in the spleen in BALB/c as well as in C57BL/6 mice. This discrepancy in viral concentrations between cytotoxicity assays performed in vivo and in vitro cautions against drawing from in vitro data far-reaching conclusions about the situation in vivo.

Of course, our identification of T cells and DCs as important sources of Il10 during acute LCMV infection does not preclude further cell types, such as myeloid-derived suppressor cells, as major producers of Il10 (reviewed by Goh et $\mathrm{al}^{40}$ ), contributing to the total effect of Il10 to various degrees in different organs during acute LCMV infection.

\section{LCMV-Induced Immunopathology}

Enhanced cytotoxic T-cell responses may cause more adverse effects. We, therefore, performed systematic characterization of the consequences of Il10 deficiency on three defined immunopathological responses, that is, DTH in the footpad, hepatitis, and the eponymous choriomeningitis, induced by acute primary infection with the WE strain of LCMV via s.c., i.p., and i.c. injection, respectively.

Regarding the natural route of infection and the specific effects of different experimental routes of infection, LCMV infection requires specific considerations.

The most common natural infection of mice with LCMV is vertical transmission from persistently infected females to 
embryos in utero or to their offspring during the first days after birth. In utero infection with this virus, which infects almost any murine cell type, occurs inevitably via the bloodstream. After birth, the pups are infected via shedding of LCMV at high concentrations in excrement and body fluids from their mothers. Fresh aerosols of body fluids from persistently LCMV-infected mice are the most common route of infection in humans also. Thus, the s.c., i.p., or i.c. route of virus inoculation are not used for mimicking natural infections. They are rather used as distinct models allowing in vivo and ex vivo experimentation in a highly reproducible setting. This way, LCMV immunology has contributed to revealing many important basic mechanisms of infection and immunity (reviewed by Zinkernagel ${ }^{41}$ and Oldstone ${ }^{42}$ ).

Subcutaneous inoculation of LCMV into the hind footpad induces an immunopathologically mediated DTH reaction, that is, a transient footpad-swelling response, which is sequentially mediated by virus-induced $\mathrm{CD} 8^{+}$and $\mathrm{CD} 4^{+} \mathrm{T}$ cells. ${ }^{26} 1110^{-1-}$ mice of both the C57BL/6 and the BALB/c strains developed a stronger swelling reaction than did the respective wt controls, suggesting, indeed, an adverse effect of Il10 deficiency on the development of DTH. The absolute increase of the swelling in $1110^{-1-}$ mice, although being statistically significant, may not appear impressive. It should be considered, however, that the skin of a mouse's paws is relatively tight and limited in its flexibility for volume increases of the paw. Therefore, the strong resistance of the skin against the swelling should be kept in mind when assessing the biological relevance of the limited increase in swelling compared with that in wt controls.

After i.p. injection, LCMV induces a fulminant but transient hepatitis in mice. ${ }^{36}$ This immunopathology is consecutively mediated by the activity of natural killer cells, $\mathrm{CD} 8^{+}$ $\mathrm{T}$ lymphocytes, and $\mathrm{CD}^{+}{ }^{+} \mathrm{T}$ lymphocytes ${ }^{43}$; this mediation does not require direct cell-to-cell contact between cytotoxic $\mathrm{T}$ lymphocytes and virus-infected hepatocytes. ${ }^{44}$ However, histopathological analysis and serum aminotransferase measurements did not reveal any differences regardless of the strain of mice. Apparently, the vigorous T-cell response in the liver cannot be further intensified by the ablation of Il10.

The most severe LCMV-induced immunopathology is fatal choriomeningitis after i.c. inoculation of the virus. ${ }^{37}$ The fulminant fatality among the majority of both $\mathrm{IllO}^{-1-}$ and wt mice in a narrow timeframe prevented direct analysis of underlying immunoregulatory mechanisms. However, the course of the disease can be slowed by partial impairment of the cytolytic activity of $\mathrm{CD}^{+} \mathrm{T}$ cells. The prototypic example is Perf $^{-1-}$ mice. In Perf ${ }^{-1-}$ mice infected with LCMV i.c., T lymphocytes are continually stimulated by the high viral load to secrete large quantities of proinflammatory cytokines, leading to a protracted wasting syndrome. ${ }^{16,38}$ The majority of $1110^{-1-} / \mathrm{Perf}^{-1-}$ mice of both the C57BL/6 and the $B A L B / c$ strains succumbed after i.c. inoculation of LCMV, whereas a significantly smaller percentage of the Il10-proficient Perf $^{-1-}$ controls died. Specifically, strongly increased lymphatic infiltrates and more pronounced inflammatory activation of microglia within the brain were accompanied by significantly elevated serum levels of proinflammatory cytokines, which contribute to the fatal LCMVinduced wasting disease. ${ }^{38}$ Thus, local and systemic parameters were indicative of the cellular mechanisms that increase the risk for mortality in $1110^{-1-}$ mice infected with LCMV i.c.

Collectively, the strongly increased activity of LCMVspecific $\mathrm{CD} 8^{+} \mathrm{T}$ cells in Il10-deficient mice was accompanied by increased LCMV-related immunopathology. Notably, a differential impact of Il10 on LCMV-induced immunopathology was observed in various nonlymphatic target organs. Clearly, the therapeutic manipulation of the immunosuppressive master regulator IL10 requires further in-depth characterization of possible adverse effects.

\section{Acknowledgments}

We thank the following people for providing breeding pairs of the indicated genetically modified lines of mice: Drs. Werner Müller (Institute for Genetics, Cologne, Germany) for C57BL/6 $1110^{-1-}$ and C57BL/6 $1110^{f / f l}$, Donna Rennick (DNAX, Palo Alto, CA) for BALB/c $I l 10^{-1-}$, Axel Roers (Technical University Dresden, Dresden, Germany) for $\mathrm{BALB} / \mathrm{c} I l 10^{f / f} / C D 4 C r e^{p o s}$, Boris Reizis (Columbia University, New York, NY) for CD11cCre $e^{\text {pos }}$, and Hans Hengartner (University of Zürich, Zürich, Switzerland) for Perf $^{-1-}$. We also thank Sandra Schramm, Mariana Carstov, and Petra Hofmann for technical assistance, and Manual Ackermann, Peter Brünker, Denise Rockhoff, Andrea Schmitz, and Johann van de Burgwal (Medical Center of the Univeristy of Cologne) for support in animal caretaking. O.U. thanks Natascha Bullmann for inspiring discussions.

\section{References}

1. Moore KW, O'Garra A, de Waal Malefyt R, Vieira P, Mosmann TR: Interleukin-10. Annu Rev Immunol 1993, 11:165-190

2. O'Garra A, Barrat FJ, Castro AG, Vicari A, Hawrylowicz C: Strategies for use of IL-10 or its antagonists in human disease. Immunol Rev 2008, 223:114-131

3. McKinstry KK, Strutt TM, Buck A, Curtis JD, Dibble JP, Huston G, Tighe M, Hamada H, Sell S, Dutton RW, Swain SL: IL-10 deficiency unleashes an influenza-specific Th17 response and enhances survival against high-dose challenge. J Immunol 2009, 182:7353-7363

4. Sun J, Madan R, Karp CL, Braciale TJ: Effector T cells control lung inflammation during acute influenza virus infection by producing IL10. Nat Med 2009, 15:277-284

5. Sarangi PP, Sehrawat S, Suvas S, Rouse BT: IL-10 and natural regulatory T cells: two independent anti-inflammatory mechanisms in herpes simplex virus-induced ocular immunopathology. J Immunol 2008, 180:6297-6306

6. Oakley OR, Garvy BA, Humphreys S, Qureshi MH, Pomeroy C: Increased weight loss with reduced viral replication in interleukin-10 knock-out mice infected with murine cytomegalovirus. Clin Exp Immunol 2008, 151:155-164

7. Jones M, Ladell K, Wynn KK, Stacey MA, Quigley MF, Gostick E, Price DA, Humphreys IR: IL-10 restricts memory T cell inflation during cytomegalovirus infection. J Immunol 2010, 185:3583-3592 
8. Humphreys IR, de Trez C, Kinkade A, Benedict CA, Croft M, Ware CF: Cytomegalovirus exploits IL-10-mediated immune regulation in the salivary glands. J Exp Med 2007, 204:1217-1225

9. Brooks DG, Trifilo MJ, Edelmann KH, Teyton L, McGavern DB, Oldstone MB: Interleukin-10 determines viral clearance or persistence in vivo. Nat Med 2006, 12:1301-1309

10. Ejrnaes M, Filippi CM, Martinic MM, Ling EM, Togher LM, Crotty S, von Herrath MG: Resolution of a chronic viral infection after interleukin-10 receptor blockade. J Exp Med 2006, 203:2461-2472

11. Ng CT, Oldstone MB: IL-10: achieving balance during persistent viral infection. Curr Top Microbiol Immunol 2014, 380:129-144

12. Locksley RM, Heinzel FP, Sadick MD, Holaday BJ, Gardner KD Jr: Murine cutaneous leishmaniasis: susceptibility correlates with differential expansion of helper T-cell subsets. Ann Inst Pasteur Immunol 1987, 138:744-749

13. Karupiah G: Type 1 and type 2 cytokines in antiviral defense. Vet Immunol Immunopathol 1998, 63:105-109

14. Tacchini-Cottier F, Weinkopff T, Launois P: Does T helper differentiation correlate with resistance or susceptibility to infection with 1 . major? Some insights from the murine model. Front Immunol 2012, 3:32

15. Kuhn R, Lohler J, Rennick D, Rajewsky K, Muller W: Interleukin-10deficient mice develop chronic enterocolitis. Cell 1993, 75:263-274

16. Kagi D, Ledermann B, Burki K, Seiler P, Odermatt B, Olsen KJ, Podack ER, Zinkernagel RM, Hengartner H: Cytotoxicity mediated by $\mathrm{T}$ cells and natural killer cells is greatly impaired in perforin-deficient mice. Nature 1994, 369:31-37

17. Roers A, Siewe L, Strittmatter E, Deckert M, Schluter D, Stenzel W, Gruber AD, Krieg T, Rajewsky K, Muller W: T cell-specific inactivation of the interleukin 10 gene in mice results in enhanced $\mathrm{T}$ cell responses but normal innate responses to lipopolysaccharide or skin irritation. J Exp Med 2004, 200:1289-1297

18. Lee PP, Fitzpatrick DR, Beard C, Jessup HK, Lehar S, Makar KW, Perez-Melgosa M, Sweetser MT, Schlissel MS, Nguyen S, Cherry SR, Tsai JH, Tucker SM, Weaver WM, Kelso A, Jaenisch R, Wilson CB: A critical role for Dnmt1 and DNA methylation in T cell development, function, and survival. Immunity 2001, 15:763-774

19. Caton ML, Smith-Raska MR, Reizis B: Notch-RBP-J signaling controls the homeostasis of CD8- dendritic cells in the spleen. J Exp Med 2007, 204:1653-1664

20. Herz J, Pardo J, Kashkar H, Schramm M, Kuzmenkina E, Bos E, Wiegmann K, Wallich R, Peters PJ, Herzig S, Schmelzer E, Kronke M, Simon MM, Utermohlen O: Acid sphingomyelinase is a key regulator of cytotoxic granule secretion by primary T lymphocytes. Nat Immunol 2009, 10:761-768

21. Lehmann-Grube F, Assmann U, Loliger C, Moskophidis D, Lohler J: Mechanism of recovery from acute virus infection. I. Role of T lymphocytes in the clearance of lymphocytic choriomeningitis virus from spleens of mice. J Immunol 1985, 134:608-615

22. Brunner KT, Mauel J, Cerottini JC, Chapuis B: Quantitative assay of the lytic action of immune lymphoid cells on 51-Cr-labelled allogeneic target cells in vitro; inhibition by isoantibody and by drugs. Immunology 1968 , 14:181-196

23. Gegin C, Lehmann-Grube F: Control of acute infection with lymphocytic choriomeningitis virus in mice that cannot present an immunodominant viral cytotoxic T lymphocyte epitope. J Immunol 1992, 149:3331-3338

24. Cobbold S, Waldmann H: Skin allograft rejection by L3/T4+ and Lyt$2+$ T cell subsets. Transplantation 1986, 41:634-639

25. Qin S, Cobbold S, Tighe H, Benjamin R, Waldmann H: CD4 monoclonal antibody pairs for immunosuppression and tolerance induction. Eur J Immunol 1987, 17:1159-1165

26. Moskophidis D, Lehmann-Grube F: Virus-induced delayed-type hypersensitivity reaction is sequentially mediated by $\mathrm{CD} 8+$ and CD4+ T lymphocytes. Proc Natl Acad Sci U S A 1989, 86: 3291-3295

27. Ishak K, Baptista A, Bianchi L, Callea F, De Groote J, Gudat F, Denk H, Desmet V, Korb G, MacSween RN, Philips MJ, Portmann BG,
Poulsen H, Scheuer PJ, Schmid M, Thaler H: Histological grading and staging of chronic hepatitis. J Hepatol 1995, 22:696-699

28. Montesinos-Rongen M, Sanchez-Ruiz M, Brunn A, Hong K, Bens S, Perales SR, Cigudosa JC, Siebert R, Deckert M: Mechanisms of intracerebral lymphoma growth delineated in a syngeneic mouse model of central nervous system lymphoma. J Neuropathol Exp Neurol 2013, 72: $325-336$

29. Moskophidis D, Cobbold SP, Waldmann H, Lehmann-Grube F: Mechanism of recovery from acute virus infection: treatment of lymphocytic choriomeningitis virus-infected mice with monoclonal antibodies reveals that Lyt-2+ T lymphocytes mediate clearance of virus and regulate the antiviral antibody response. J Virol 1987, 61:1867-1874

30. Wiesel M, Oxenius A: From crucial to negligible: functional CD8(+) T-cell responses and their dependence on CD4(+) T-cell help. Eur J Immunol 2012, 42:1080-1088

31. Chaudhri G, Panchanathan V, Buller RM, van den Eertwegh AJ, Claassen E, Zhou J, de Chazal R, Laman JD, Karupiah G: Polarized type 1 cytokine response and cell-mediated immunity determine genetic resistance to mousepox. Proc Natl Acad Sci U S A 2004, 101:9057-9062

32. Parish IA, Marshall HD, Staron MM, Lang PA, Brustle A, Chen JH, Cui W, Tsui YC, Perry C, Laidlaw BJ, Ohashi PS, Weaver CT, Kaech SM: Chronic viral infection promotes sustained Th1-derived immunoregulatory IL-10 via BLIMP-1. J Clin Invest 2014, 124: 3455-3468

33. Baca Jones C, Filippi C, Sachithanantham S, Rodriguez-Calvo T, Ehrhardt K, von Herrath M: Direct infection of dendritic cells during chronic viral infection suppresses antiviral $\mathrm{T}$ cell proliferation and induces IL-10 expression in CD4 T cells. PLoS One 2014, 9:e90855

34. Richter K, Perriard G, Behrendt R, Schwendener RA, Sexl V, Dunn R, Kamanaka M, Flavell RA, Roers A, Oxenius A: Macrophage and T cell produced IL-10 promotes viral chronicity. PLoS Pathog 2013, 9: e1003735

35. Ng CT, Oldstone MB: Infected CD8alpha- dendritic cells are the predominant source of IL-10 during establishment of persistent viral infection. Proc Natl Acad Sci U S A 2012, 109:14116-14121

36. Zinkernagel RM, Haenseler E, Leist T, Cerny A, Hengartner H, Althage A: T cell-mediated hepatitis in mice infected with lymphocytic choriomeningitis virus. Liver cell destruction by $\mathrm{H}-2$ class I-restricted virus-specific cytotoxic T cells as a physiological correlate of the 51Cr-release assay? J Exp Med 1986, 164: $1075-1092$

37. Lehmann-Grube F: Lymphocytic choriomeningitis virus. New York, Springer-Verlag, 1971

38. Kamperschroer C, Quinn DG: The role of proinflammatory cytokines in wasting disease during lymphocytic choriomeningitis virus infection. J Immunol 2002, 169:340-349

39. Ahmed R, Butler LD, Bhatti L: T4 + T helper cell function in vivo: differential requirement for induction of antiviral cytotoxic T-cell and antibody responses. J Virol 1988, 62:2102-2106

40. Goh C, Narayanan S, Hahn YS: Myeloid-derived suppressor cells: the dark knight or the joker in viral infections? Immunol Rev 2013, 255: 210-221

41. Zinkernagel RM: Lymphocytic choriomeningitis virus and immunology. Curr Top Microbiol Immunol 2002, 263:1-5

42. Oldstone MB: Biology and pathogenesis of lymphocytic choriomeningitis virus infection. Curr Top Microbiol Immunol 2002, 263: $83-117$

43. Gossmann J, Lohler J, Utermohlen O, Lehmann-Grube F: Murine hepatitis caused by lymphocytic choriomeningitis virus. II. Cells involved in pathogenesis. Lab Invest 1995, 72:559-570

44. Wohlleber D, Kashkar H, Gartner K, Frings MK, Odenthal M, Hegenbarth S, Borner C, Arnold B, Hammerling G, Nieswandt B, van Rooijen N, Limmer A, Cederbrant K, Heikenwalder M, Pasparakis M, Protzer U, Dienes HP, Kurts C, Kronke M, Knolle PA: TNF-induced target cell killing by CTL activated through cross-presentation. Cell Rep 2012, 2:478-487 